\title{
The Indus basin in the framework of current and future water resources management
}

\author{
A. N. Laghari ${ }^{1}$, D. Vanham ${ }^{2}$, and W. Rauch $^{2}$ \\ ${ }^{1}$ Energy \& Environment Engineering Department, Quaid-E-Awam University of Engineering, Science \& Technology \\ (QUEST), Nawabshah, Pakistan \\ ${ }^{2}$ Unit of Environmental Engineering, Institute of Infrastructure, University Innsbruck, Technikerstrasse 13, \\ 6020 Innsbruck, Austria
}

Correspondence to: D. Vanham (davy.vanham@uibk.ac.at, davy.vanham@yahoo.de)

Received: 8 February 2011 - Published in Hydrol. Earth Syst. Sci. Discuss.: 2 March 2011

Revised: 6 March 2012 - Accepted: 18 March 2012 - Published: 2 April 2012

\begin{abstract}
The Indus basin is one of the regions in the world that is faced with major challenges for its water sector, due to population growth, rapid urbanisation and industrialisation, environmental degradation, unregulated utilization of the resources, inefficient water use and poverty, all aggravated by climate change. The Indus Basin is shared by 4 countries Pakistan, India, Afghanistan and China. With a current population of 237 million people which is projected to increase to 319 million in 2025 and 383 million in 2050, already today water resources are abstracted almost entirely (more than $95 \%$ for irrigation). Climate change will result in increased water availability in the short term. However in the long term water availability will decrease. Some current aspects in the basin need to be re-evaluated. During the past decades water abstractions - and especially groundwater extractions have augmented continuously to support a rice-wheat system where rice is grown during the kharif (wet, summer) season (as well as sugar cane, cotton, maize and other crops) and wheat during the rabi (dry, winter) season. However, the sustainability of this system in its current form is questionable. Additional water for domestic and industrial purposes is required for the future and should be made available by a reduction in irrigation requirements. This paper gives a comprehensive listing and description of available options for current and future sustainable water resources management (WRM) within the basin. Sustainable WRM practices include both water supply management and water demand management options. Water supply management options include: (1) reservoir management as the basin is characterised by a strong seasonal behaviour in water availability (monsoon and meltwater) and water demands; (2) water quality conservation and investment in wastewater infrastructure; (3)
\end{abstract}

the use of alternative water resources like the recycling of wastewater and desalination; (4) land use planning and soil conservation as well as flood management, with a focus on the reduction of erosion and resulting sedimentation as well as the restoration of ecosystem services like wetlands and natural floodplains. Water demand management options include: (1) the management of conjunctive use of surface and groundwater; as well as (2) the rehabilitation and modernization of existing infrastructure. Other demand management options are: (3) the increase of water productivity for agriculture; (4) crop planning and diversification including the critical assessment of agricultural export, especially (basmati) rice; (5) economic instruments and (6) changing food demand patterns and limiting post-harvest losses.

\section{Introduction}

The Indus river basin is one of the most depleted basins in the world (Sharma et al., 2010). During certain periods of the year, water even does not really reach the sea any more, making it a closed basin (Molle et al., 2010). Already today it faces large problems with respect to water resources. These will only become more challenging in the next decades, due to population growth, rapid urbanisation and industrialisation, environmental degradation, inefficient water use and poverty (economic water shortage), all aggravated by climate change.

Different aspects of the water cycle in the Indus basin have been the subject of several studies, e.g. hydrology and available water resources (Winiger et al., 2005; Archer, 2003; Immerzeel et al., 2010; Kaser et al., 2010), the impact of climate 
change on glaciers and the hydrological regime (Akhtar et al., 2008; Immerzeel et al., 2010; Tahir et al., 2011), agricultural water demands and productivity (Cai and Sharma, 2009, 2010), groundwater management (Kerr, 2009; Qureshi et al., 2009; Scott and Sharma, 2009; Shah et al., 2006), reservoir sedimentation (Khan and Tingsanchali, 2009), ecological flows and the Indus delta (Leichenko and Wescoat, 1993), water policy (Biswas, 1992; Miner et al., 2009; Shah et al., 2006, 2009; Sharma et al., 2010) and water resources management (Archer et al., 2010; Qureshi et al., 2009).

Within the two latter publications the major challenges facing the Indus basin were described, as well as recommendations for sustainable water management. However, both papers have certain limitations. They both focused only on Pakistan, although $40 \%$ of the basin's surface area is located within 3 other countries. Qureshi et al. (2009) focused on groundwater. The recommendations for sustainable water management within Archer et al. (2010) were far from complete, as not all available options were accounted for. Within this latter paper the focus is on water supply management options. The part on "water resources management" is not sufficient, and water demand management options are not addressed. In a world with finite (water) resources the solution is not only in supply management but sustainable management options require the inclusion of demand management practices. The aim of this paper is to give an overview on all relevant recommendations for the whole Indus basin.

This paper gives a comprehensive listing and description of all available water resources management options and does not restrict itself to the Pakistani part of the Indus basin. Especially the Indian part of the basin is also included in the analysis. Also the topic of flooding and especially the massive floods of 2010 are discussed. The paper also gives a comprehensive overview on water balance quantities obtained from different sources, which is currently not available in the literature.

\section{The Indus basin}

\subsection{General}

The Indus basin is located in 4 countries, of which the largest part in Pakistan, and substantial upstream parts in India, China and Afghanistan (Fig. 1). More than $40 \%$ is located at an elevation higher than $2000 \mathrm{~m}$ a.s.l. The total hydrographic basin - as defined by the International Water Management Institute (IWMI) - has an area of $1137819 \mathrm{~km}^{2}$. Other authors (Babel and Wahid, 2008; Eastham et al., 2010; Harrington et al., 2009; Hoekstra and Mekonnen, 2011; Jain et al., 2009) indicate an area range from 1080000 to $1218500 \mathrm{~km}^{2}$. Of a total population of about 237 million (Fig. 1), Pakistan accounts for $61 \%$ (145 million) and India for $35 \%$ (83 million). Another 4\% (9 million) live in the Afghani part of the basin, and the Chinese population is very little due to the rough
Himalayan landscape character of this part of the basin. Of the irrigated area $\left(228694 \mathrm{~km}^{2}, 21 \%\right.$ of basin area) about $60.9 \%$ is located in Pakistan, $37.2 \%$ in India, $1.9 \%$ in Afghanistan and $0 \%$ in China. The Indus Basin Irrigation System (IBIS) is the largest irrigation system in the world. Water demands are thus by far the highest in Pakistan followed by India. The focus of this paper will therefore be on these two regions.

The wettest regions of the Indus basin are on the southern slopes of the Himalaya-Karakoram-Hindu Kush (HKH) mountain range (Fig. 2). The high mountain ranges in the north of the basin - like Ladakh in India - are very dry, as well as the lowlands. The aridity index within the basin ranges from humid to hyper-arid. The glacial area is very large, i.e. $37134 \mathrm{~km}^{2}$ according to the DCW database (Raup et al., 2000). Within the GLIMS-Database (Armstrong et al., 2005) glaciers from India and Pakistan are missing. The latter is definitely more accurate than the DCW database, which overestimates the glacial area for the region. Other sources that refer to the GLIMS-database indicate within the Indus basin a glacial area of about $22000 \mathrm{~km}^{2}$ (Immerzeel et al., 2010) or $20325 \mathrm{~km}^{2}$ (Kaser et al., 2010). These values are more realistic estimates.

\subsection{Water balance}

General water balance components have been quantified by different authors and are shown in Fig. 3. Based upon computations from the 2 datasets (GWSP, 2008; Hijmans et al., 2005) and values given by different authors (Immerzeel et al., 2010; Karim and Veizer, 2002; Mitchell and Jones, 2005), the average annual basin precipitation is within the range 392 to $461 \mathrm{~mm}$ or 446 to $497 \mathrm{~km}^{3}$, for the periods 1950 2000, 1961-2000 and 2001-2007. Varis et al. (2012) indicate that the annual precipitation in the Indus basin is less than $500 \mathrm{~mm}$. The Indian part of the basin receives about the same volume in precipitation as the Pakistani part. The Challenge Program on Water and Food (CPWF) identifies substantial higher values of precipitation for the basin, i.e. 762 $824 \mathrm{~km}^{3}$ (Eastham et al., 2010; Harrington et al., 2009). Especially for the mountainous part of the basin the latter authors state much higher precipitation values, e.g. annually $1130 \mathrm{~mm}$ for the entire Upper Indus basin. This is a very high value as compared to other sources, e.g. Bookhagen and Burbank (2010) state annually $0.3 \mathrm{~m}$ for the Upper Indus basin or Immerzeel et al. (2009) state $340 \mathrm{~mm}$. These amounts are coherent with the precipitation map of Fig. $2 b$, where it is shown that the high mountain ranges in the north of the basin are very dry.

Total basin long term average water availability - renewable water resources - (surface and groundwater) adds up to $287 \mathrm{~km}^{3}$ (Sharma et al., 2008; IUCN, 2010) or $252 \mathrm{~mm}$ annually. The Indian part of the basin (including the Chinese upstream part) accounts for $97 \mathrm{~km}^{3}$ whereas the Pakistani part (including the Afghani upstream part) accounts for 


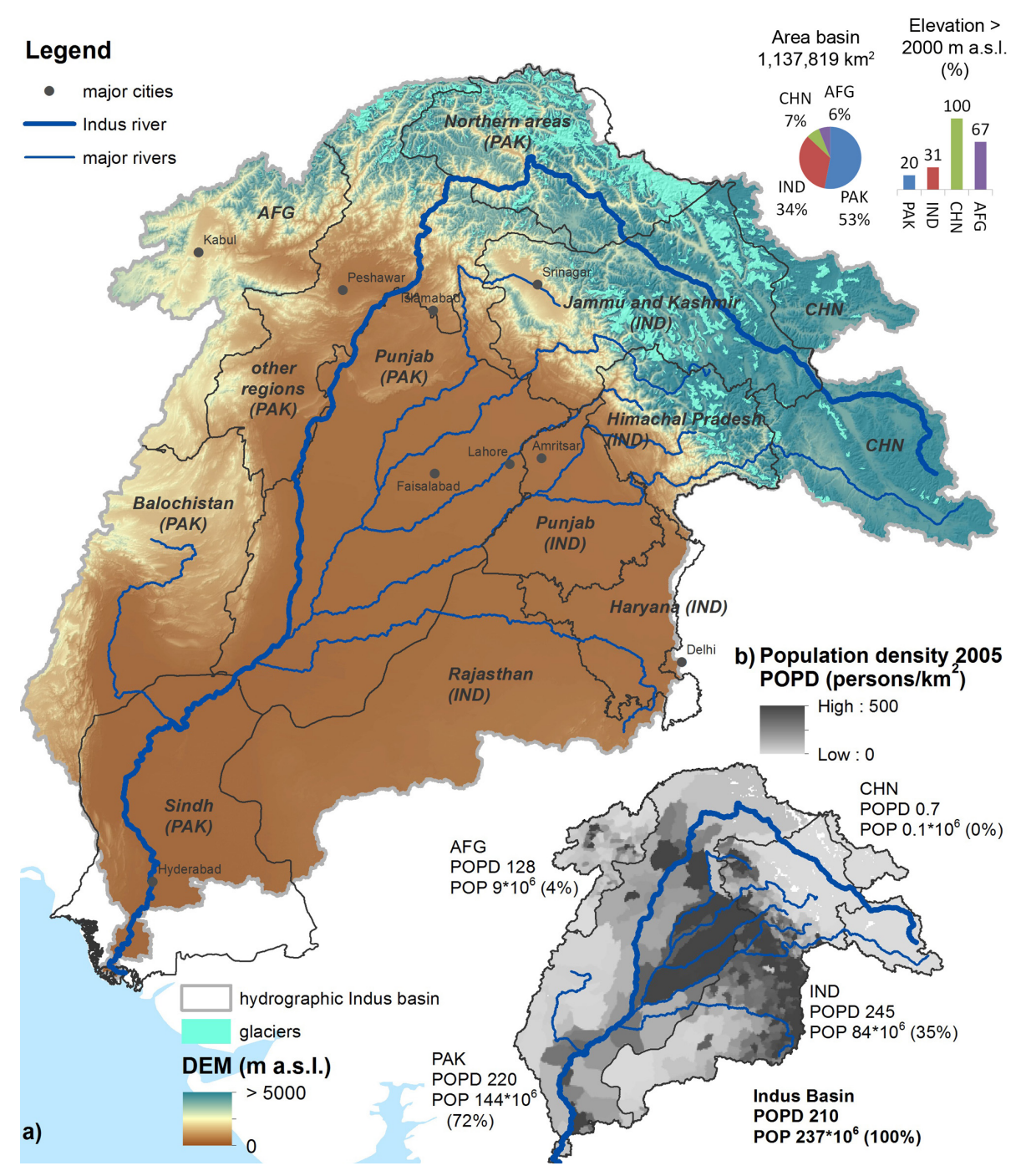

Fig. 1. (a) Overview of the DEM and location of political borders of the Indus river basin (boundaries based upon topography, as provided by the IWMI); (b) population density POPD (persons per $\mathrm{km}^{2}$ ) in 2005 according to CIESIN (2005), POP = total population in 2005 based upon the GPWv3 dataset (CIESIN, 2005); country codes according to the UN: AFG = Afghanistan, $\mathrm{CHN}=\mathrm{China}, \mathrm{IND}=\mathrm{India}, \mathrm{PAK}=\mathrm{Pakistan}$.

$190 \mathrm{~km}^{3}$. Basin long term average surface water availability is in the order $239 \mathrm{~km}^{3}$ (Hoekstra and Mekonnen, 2011) to $258 \mathrm{~km}^{3}$ (Gupta and Deshpande, 2004; Kreutzmann, 2011; Sharma et al., 2008). In India, surface water availability is $73 \mathrm{~km}^{3}$ (Gupta and Deshpande, 2004; Sharma et al., 2008) and the Pakistani part accounts for $175 \mathrm{~km}^{3}$ (Briscoe and Qamar, 2007) or $185 \mathrm{~km}^{3}$ (Kreutzmann, 2011). This includes $165 \mathrm{~km}^{3}$ from the 3 western rivers (Indus, Chenab, and Jehlum) and $10 \mathrm{~km}^{3}$ from the eastern rivers (Ravi, Beas, and Sutlej). Afghani surface water availability is $25 \mathrm{~km}^{3}$ (Qureshi, 2011) and is included in the latter Pakistani volumes. Replenishable groundwater resources in India are $27 \mathrm{~km}^{3}$ (Sharma et al., 2008) and in Pakistan $63 \mathrm{~km}^{3}$ (Briscoe and Qamar, 2007; Qureshi, 2011). There is an overlap between available surface water resources (about $250 \mathrm{~km}^{3}$ ) and replenishable groundwater resources (about $100 \mathrm{~km}^{3}$ ).
Especially in Pakistan, a substantial part of available water resources diverted in the IBIS canal system leads to the recharge of the groundwater reservoir. According to Van Steenbergen and Gohar (2005), only $21 \%\left(14 \mathrm{~km}^{3}\right)$ of the Pakistani replenishable groundwater resources (total $63 \mathrm{~km}^{3}$ ) originate directly from rainfall. About $45 \%$ originate from recharge from the canal system, $26 \%$ from irrigation return flows and $6 \%$ from river recharge. The remaining $2 \%$ originate from other return flows. The Indus Basin is underlain by an extensive unconfined aquifer that covers 16 million ha of surface area, of which 6 million ha are fresh and the remaining 10 million ha are saline (Qureshi et al., 2008).

Irrigated agriculture currently accounts for more than $95 \%$ of blue water withdrawals in the Indus basin (Fig. 3). The major agricultural zones are located in the Pakistani and Indian provinces of Punjab (Fig. 4). Also the Sindh province 


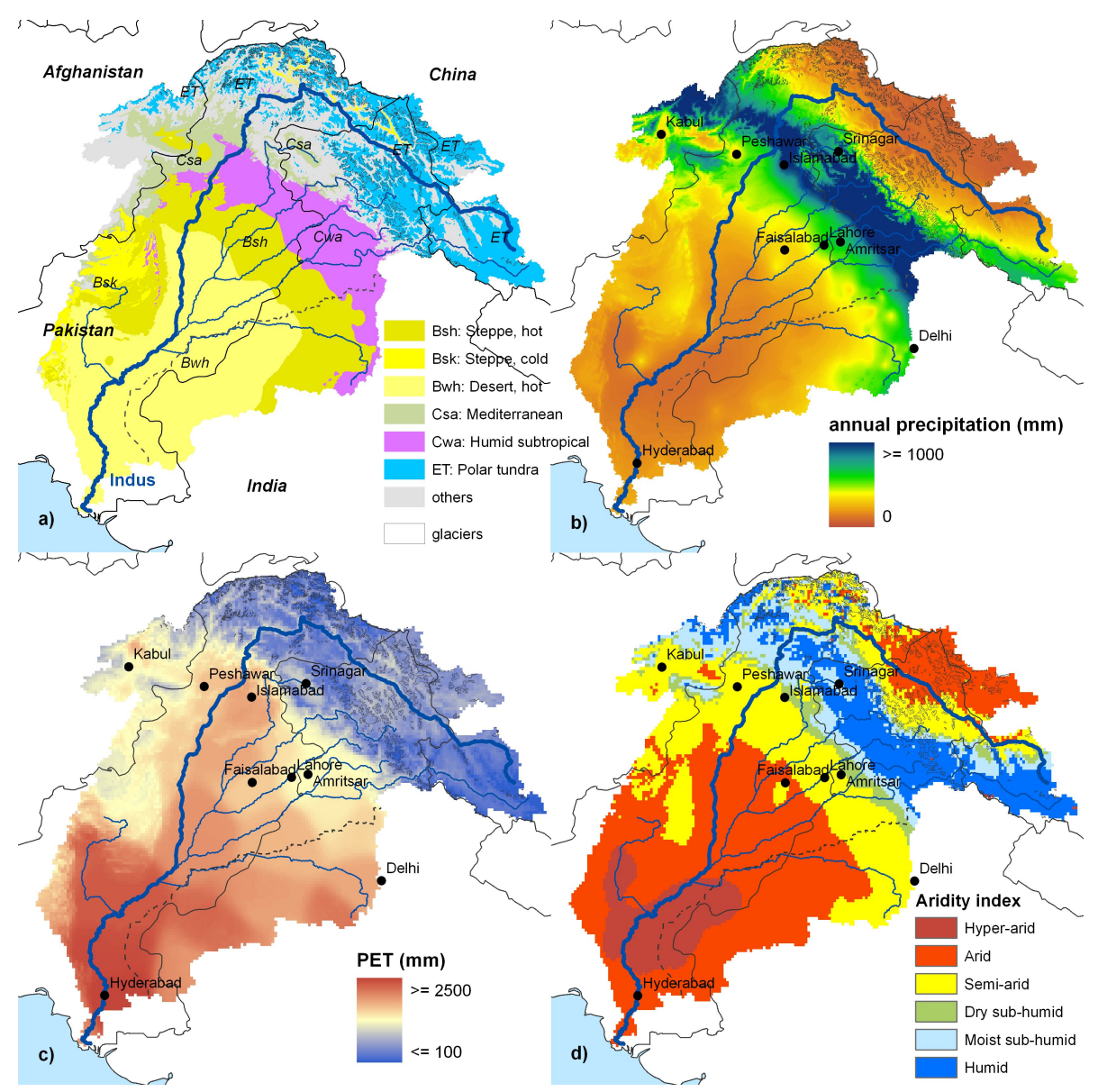

Fig. 2. Climatology within the Indus basin: (a) major climatic zones 1950-2000 - the Köppen-Geiger system of climate classification (Köppen, 1936) adapted according to Hijmans et al. (2005) by de Bie (2007); (b) average annual precipitation (mm) for the period 19502000, according to Hijmans et al. (2005); (c) average annual potential evapotranspiration PET in mm (interpolated surface from FAOClimDatabase) calculated as ETo after the FAO Penman-Monteith equation (Allen et al., 1998); (d) aridity index $(\mathrm{AI}=\mathrm{PET} / \mathrm{P})$ as defined by UNEP (1992).

in Pakistan is an important agricultural area as well as the Indian province of Haryana; the major irrigation system is located in these regions. The harvested area of the three crops wheat, rice and cotton represent $77 \%$ of the area of all crops harvested under irrigation (33 million ha) (Fig. 4). Total water withdrawals in India add up to $98 \mathrm{~km}^{3}$ (Saleth and Amarasinghe, 2009), of which $94 \mathrm{~km}^{3}$ is for irrigated agriculture $\left(55 \mathrm{~km}^{3}\right.$ or $59 \%$ as groundwater, $39 \mathrm{~km}^{3}$ or $41 \%$ as surface water). Total water withdrawals in Pakistan add up to $180 \mathrm{~km}^{3}$ (Briscoe and Qamar, 2007; Qureshi, 2011), of which $128 \mathrm{~km}^{3}(71 \%)$ as surface water and $52 \mathrm{~km}^{3}(29 \%)$ as groundwater. However, as indicated before the distinction between both is not absolute. A large fraction of the replenishable groundwater originates from surface water. In the Afghani part of the basin about $10 \mathrm{~km}^{3}$ are withdrawn, of which $96 \%$ is for irrigated agriculture. Water abstractions in the Chinese part of the basin are neglectable.

Water consumption values (Fig. 3) show that only about $11 \%$ of domestic water in the basin is consumed, the remaining $89 \%$ returns to the system. Industrial water is returned at $91 \%$ back to the system. There is also a large gap between water withdrawals for irrigation and actual water consumed for crop production. Dependent on the source and the assessed period, water consumption by crops in the whole basin is estimated in the range 117 to $143 \mathrm{~km}^{3}$ (GWSP, 2008; Immerzeel et al., 2010; Mekonnen and Hoekstra, 2010b). Harrington et al. (2009) estimate much higher values. Total crop consumption in India amounts to $35 \mathrm{~km}^{3}$ (Saleth and Amarasinghe, 2009) for $94 \mathrm{~km}^{3}$ withdrawn. The total consumption in the Pakistani part for irrigation ranges from $69 \mathrm{~km}^{3}$ to $99 \mathrm{~km}^{3}$ (GWSP, 2008; Kreutzmann, 2011). Irrigation efficiencies are low. Much of the surface water that enters the system is wasted (also to groundwater recharge). This is responsible for the continuous shortage of irrigation water in Pakistan and especially in tail-enders such as the Sindh province. Pakistan is close to using all its available water resources in most years in the current situation. Of the replenishable groundwater resources of $63 \mathrm{~km}^{3}, 52 \mathrm{~km}^{3}$ 


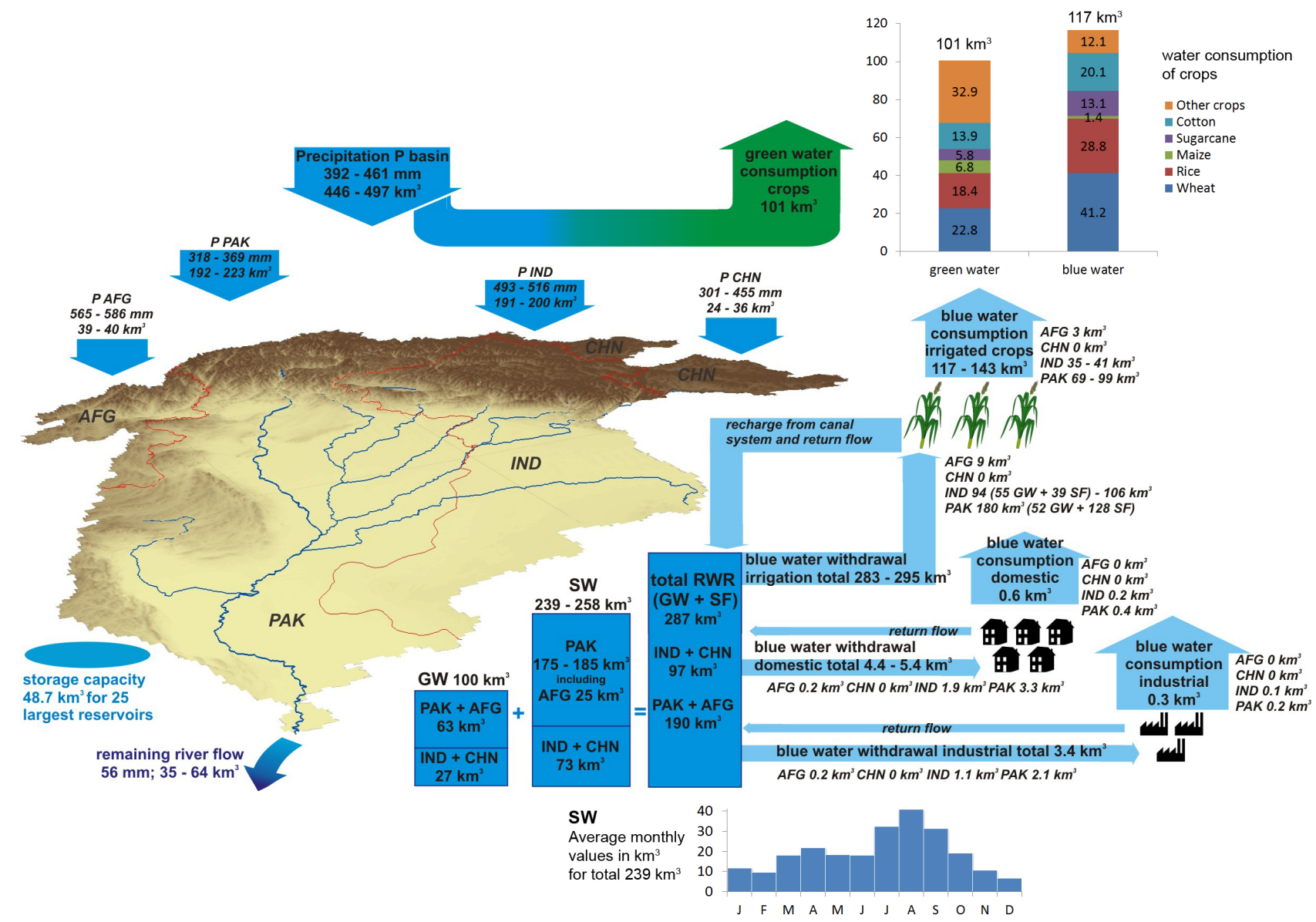

Fig. 3. Average annual water balance data of the Indus basin, based upon different sources. $P=$ precipitation; RWR $=$ renewable water resources; GW = ground water; SW = surface water. Values calculated by means of GWSP (2008) data are referred to as (1). Data sources: precipitation (1) and Hijmans et al. (2005), Immerzeel et al. (2010), Karim and Veizer (2002), Mitchell and Jones (2005); total RWR (UNEP, 2009; Sharma et al., 2008); national RWR (IUCN, 2010; Sharma et al., 2008); total SW (Hoekstra and Mekonnen, 2011; Sharma et al., 2010); national SW (Briscoe and Qamar, 2007; Gupta and Deshpande, 2004; Kreutzmann, 2011; Qureshi, 2011; Sharma et al., 2008); national GW (Briscoe and Qamar, 2007; Indian M.W.R., 2011; Qureshi, 2011; Sharma et al., 2008); total water withdrawal/consumption irrigation (1) and Immerzeel et al. (2010) and Mekonnen and Hoekstra (2010b); national water withdrawal/consumption irrigation (1) and Kreutzmann (2011) and Saleth and Amarasinghe (2009); total water withdrawal/consumption domestic and industrial (1) and Sharma et al. (2010); national water withdrawal/consumption domestic and industrial (1); remaining river flow (1) and Briscoe and Qamar (2007), Karim and Veizer (2002) and Kreutzmann (2011); storage reservoirs based upon the dataset (Lehner et al., 2008)

is used. Of the available surface water resources of $175 \mathrm{~km}^{3}$, about $75 \%$, is withdrawn. In a system with little storage and considerable variability, average values can however be deceptive. Summer or monsoon crops (kharif, autumn harvest) and winter crops (rabi, spring harvest) have different demands and water availability during these periods also differ.

Mekonnen and Hoekstra (2010b) calculated both the blue water consumption (irrigated consumption) and green water consumption of crops in the Indus basin. Large regions within the basin - with extensive agriculture - are rainfed. Irrigation of wheat, rice, cotton and sugarcane crops account for $90 \%$ of the total blue water consumption in the basin (Fig. 3). The same crops and maize account for $67 \%$ of total green water evapotranspiration in the basin.
The remaining river flow to the sea ranges from 35 to $64 \mathrm{~km}^{3}$ (Briscoe and Qamar, 2007; Karim and Veizer, 2002; Kreutzmann, 2011).

\section{Major challenges}

\subsection{Introduction}

Major challenges are foreseen for the water sector in the Indus basin. The region is under extreme pressures of population and poverty, unregulated utilization of the resources and low levels of productivity (Sharma et al., 2010). Population within the basin is projected to increase - with resulting higher water demands - and changes in water availability are 

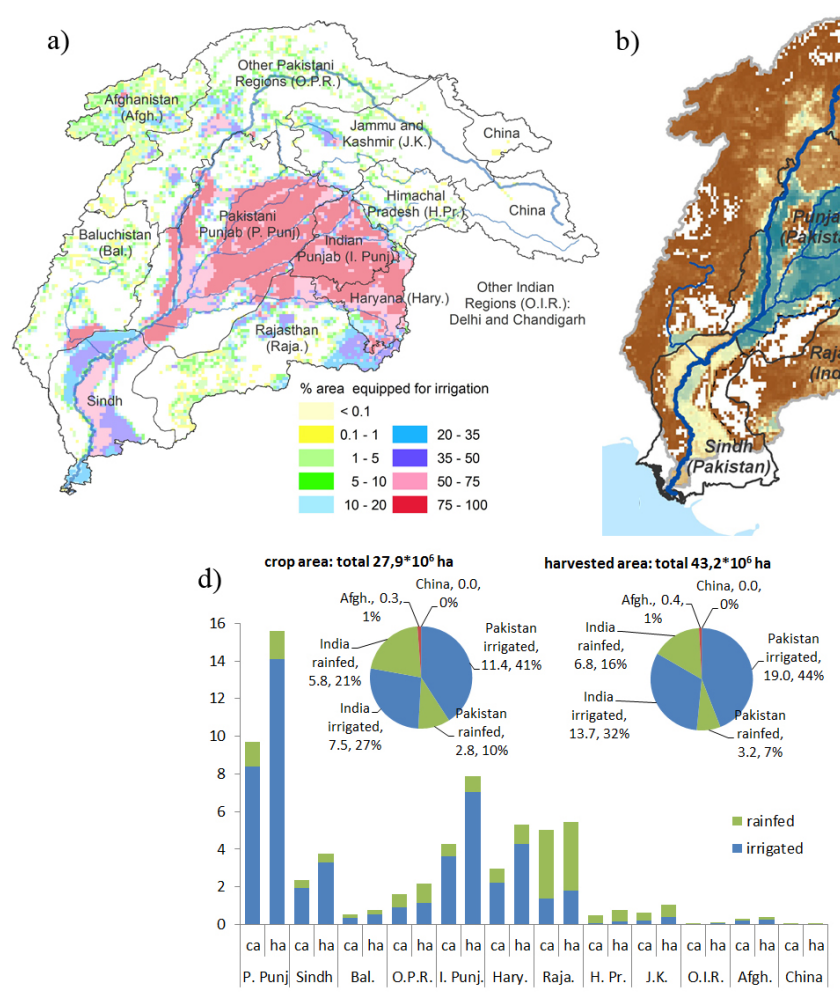
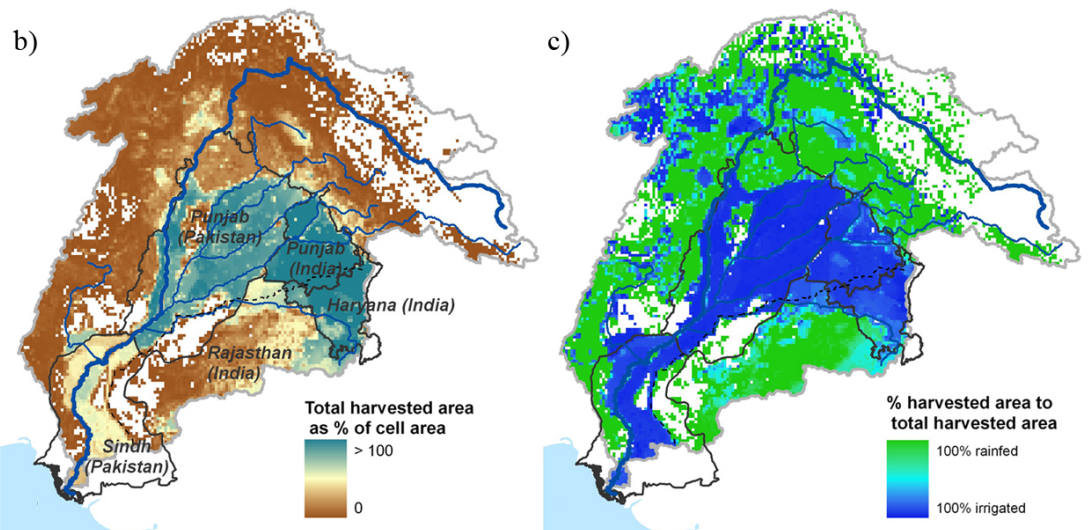

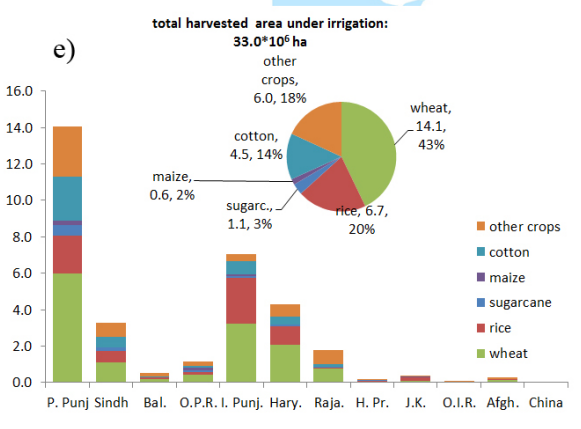

Fig. 4. Crop area ("ca" - net area) and harvested area ("ha" - gross area) within the Indus basin statistics based upon MIRCA2000data (Portmann et al., 2010): (a) principal regions within the basin with representation of $\%$ of area equipped for irrigation (FAO-database, according to Siebert et al., 2005); (b) total harvested area of both irrigated and rainfed crops as percentage of cell area; (c) relative contribution (\%) to total harvested area by irrigated crops and rain fed crops; (d) crop area and harvested area (in $10^{6}$ ha) for all crops within the regions; (e) crop area and harvested area under irrigation (in $10^{6}$ ha) for the 5 main crops - wheat, rice, sugarcane, maize and cotton.

predicted (Archer et al., 2010). On the short term climate change is expected to have a positive effect on available water resources, however, on the long term this effect will be negative. The following gives an overview of challenges for the Indus basin:

- Water resources changes due to climate change.

- Population increase and increased urbanisation and industrialisation, resulting in higher water demands for domestic and industrial purposes, food production and energy.

- A shift from surface water to groundwater use resulting in rapid depletion of groundwater resources - an observation made for both the Indus and Ganges basins.

- Flooding

Other challenges include the low water productivity in food production at particular locations; a declining reservoir storage due to sedimentation; water logging and salinity, loss of productive agricultural land, land degradation, contamination of surface and groundwater resources; an increase in environmental flows to sustain ecosystems within the rivers and the Indus delta, but also to prevent further salt water intrusion in the delta; and tension between riparian countries. The first 4 challenges are discussed more in detail within the following Sects. 3.2 to 3.5. The section with recommendations (Sect. 4) will however answer to all listed challenges.

\subsection{Water resources changes due to climate change}

Water from the sparsely inhabited upstream mountains in the Indus basin is essential for the densely inhabited semito hyper-arid lowlands (Fig. 2) with its extensive irrigation system. In many basins with mountainous regions, the seasonal storage of water in snow and ice is very important for the lowlands, so that water resources management analyses need to be conducted on at least a seasonal level (Vanham et al., 2008). Also basins with monsoonal regimes like the Indus basin require water resources management analyses on at least a seasonal level (Vanham et al., 2011b), as both available water resources and water demands (Vanham et al., 2011a) fluctuate over time. Total surface water availability in the basin has its peak in the summer months (kharif) whereas water availability is generally lower during the winter months (rabi) (Fig. 3). During the winter months 
November to February, average monthly surface water availability is about $10 \mathrm{~km}^{3}$ whereas during the summer months July to September this value is larger than $30 \mathrm{~km}^{3}$. In systems with considerable water availability and demand variability, averages can therefore be deceptive.

Immerzeel et al. (2010) showed that meltwater is extremely important in the Indus basin. For the present day climate, discharge generated by snow and glacial melt is $151 \%$ of the total discharge naturally generated in the downstream areas. About $40 \%$ of the meltwater originates from glaciers, $60 \%$ from snowpack. Also Kaser et al. (2010) stress the importance of glacial melt water to the Indus flow, as well as Tahir et al. (2011). Bookhagen and Burbank (2010) calculated the meltwater contribution to annual discharge for the major southern Himalayan catchments where the rivers flow into the plains (at the foot of the Himalayas): $66 \%$ for the Indus, $25 \%$ for the Jhelum, $43 \%$ for the Chenab, $16 \%$ for the Ravi, $21 \%$ for the Beas and $57 \%$ for the Sutlej river. Further downstream these fractions become smaller. The regimes in the basin are (Archer, 2003):

- A nival regime at middle altitudes with flow dependent on the melting of seasonal snow. The greatest contribution to total flow comes from this regime.

- A glacial regime at very high altitudes with river flow closely dependent on summer temperatures.

- A rainfall regime dependent on runoff from rainfall mainly during the monsoon season. This regime dominates on the southern foothills of the Himalayas (Fig. 2) and also over the plains but with much reduced total amounts.

Climate change will definitely affect the temporal and spatial availability of water resources. A listing of potential effects and studies conducted on the three hydrological regimes is given in Archer et al. (2010). Also Immerzeel et al. (2010) indicate that upstream snow and ice reserves of the Indus basin, important in sustaining seasonal water availability, are likely to be affected substantially by climate change, but to what extent is yet unclear. A new study by Scherler et al. (2011) actually indicates that debris coverage may be a missing link in the understanding of the decline of glaciers in the HKH. Controversy about the current state and future evolution of Himalayan glaciers has been stirred up by erroneous statements in the fourth report by the IPCC. According to Scherler et al. (2011), glaciers in the Karakoram region are mostly stagnating. This anomaly was already described by Hewitt (2005). However, glaciers in the Western, Central, and Eastern Himalaya are retreating. Half of the studied glaciers in the Karakoram region are stable or even advancing, whereas about two-thirds are in retreat elsewhere throughout High Asia. Also Tahir et al. (2011) concluded a rather slight expansion of cryosphere during the period 2000-2009 in the Hunza basin in the Upper Indus. This is in contrast to the prevailing notion that all glaciers in the HKH are retreating. Basically glaciers in the Central Karakoram are stagnating or even expanding, whereas glaciers in the Afghani part and the western Himalayas part of the Indus basin are retreating. An overview on this situation is given in Fig. 5.

There is general consent that in the Indus basin climate change will result in increased water availability in the short term. However in the long term water availability will decrease. Immerzeel et al. (2010), for example, indicate a decrease in mean upstream water supply from the upper Indus $(-8.4 \%)$ by $2046-2065$ with respect to the reference period 2000-2007. The authors indicate that these changes are considerable, but they are less than the decrease in meltwater production would suggest, because this reduction is partly compensated for by increased mean upstream rainfall (Indus $+25 \%$ ). Regardless of the compensating effects of increased rainfall, summer and late spring discharges are eventually expected to be reduced consistently and considerably around 2046 to 2065 after a period with increased flows due to accelerated glacial melt. The authors also analyzed an extreme scenario in which all glaciers are assumed to have disappeared, for which the Indus shows the largest reduction in water availability of all major Himalayan rivers. Mukhopadhyay (2012) states similar conclusions. According to the author, global warming is expected to dramatically alter the flow regime of the Upper Indus river. The predicted change in flow regime is an initial increase in summer flows in the early decades of 21 st century followed by a sharp decline of the same during the latter parts of the century. Similar results were found for the Sutlej river (Singh and Bengtsson, 2004).

Although the effects of climate change will not be as visible in the short term, they will be prominent on the long term. Reduced water availability will be the most profound during the spring and summer months. Water from the snow and glacier melt will appear earlier than the main monsoon flows.

\subsection{Increase in population}

Water demand increases for domestic and industrial purposes, food production and energy relate primarily to the predicted population increase in the basin, associated with an increase in urbanisation and industrialisation but also an increase in living standards. The current population in the basin of 237 million is projected to grow to 319 million in 2025 and 383 million in 2050 (medium population estimates) or 336 million in 2025 and 438 million in 2050 (high population estimates) (Fig. 6). Substantial population increases are predicted in all Pakistani and Indian Indus basin regions. Kabul is located in the Indus basin, and its population has tripled in size since late 2001, to approximately 4.5 million people, making it perhaps the world's fastest-growing city in the last eight years (Lashkaripour and Hussaini, 2008; 


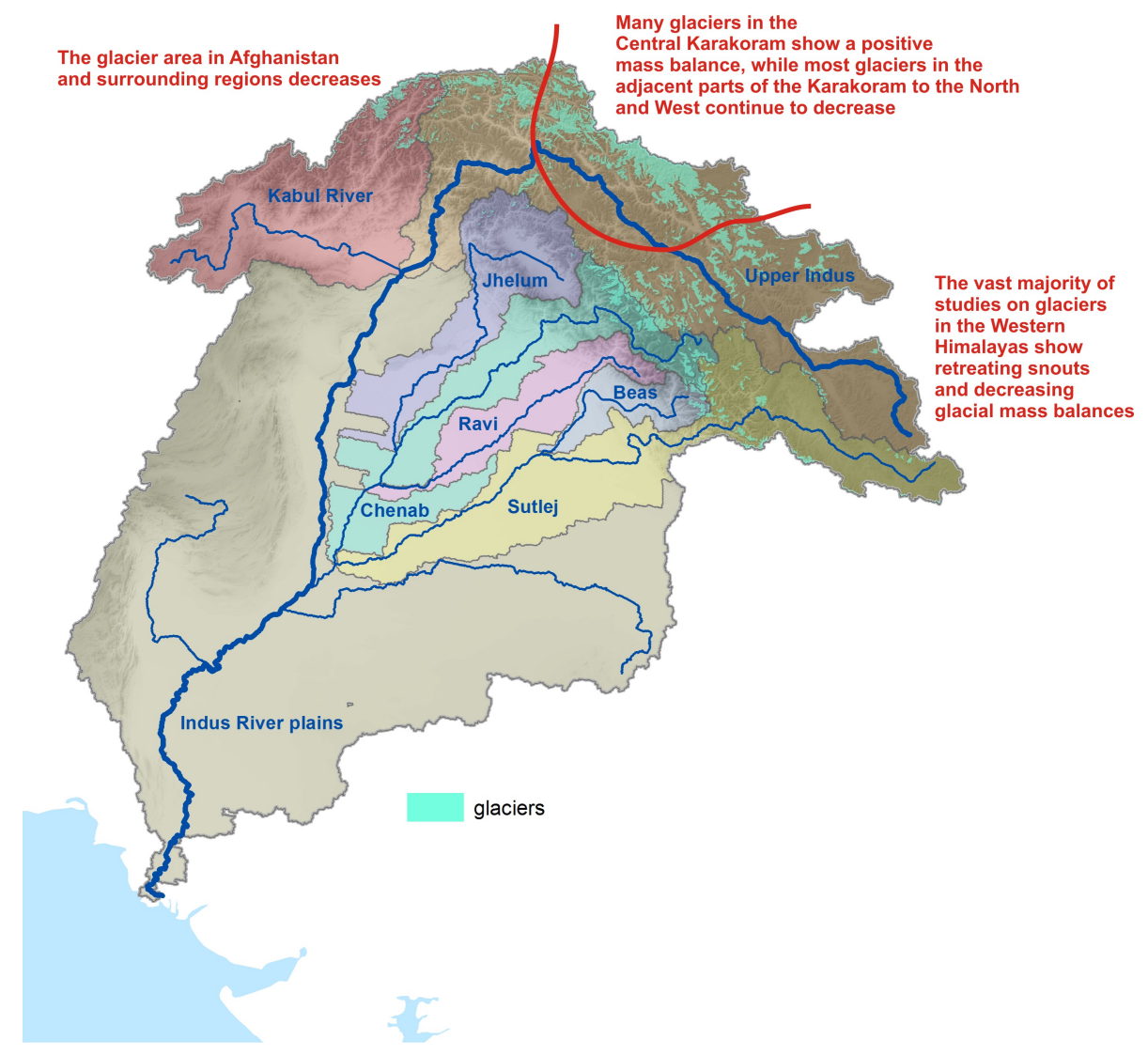

Fig. 5. Glacier behaviour in the Upper Indus Basin. Data source of Karki et al. (2011).

Setchell and Luther, 2009). The number of people that live in the Chinese part of the basin is extremely low.

\subsection{Shift from surface water to groundwater use}

During the last decades there has been a shift from surface water resources to groundwater resources within the Indus basin, for irrigation but also for domestic and industrial purposes. On demand availability of groundwater has transformed the concept of low and uncertain crop yields (before predominantly fed with surface water) into more assured crop production (Qureshi et al., 2009). The availability of inexpensive drilling technologies allows even poor farmers to access groundwater. Over $80 \%$ of the groundwater exploitation in Pakistan takes place through small capacity private tube wells. During the last decades, the number of tube wells in the main agricultural zones of the Indus basin has increased dramatically. By the early 1960s, an estimated $23 \%$ of Pakistan's land suffered from waterlogging and crop root zone salinity. Initial response was through the SCARPproject, which aimed at lowering the groundwater table by means of the instalment of 13500 publicly owned and operated tubewells (Qureshi et al., 2008).
However, the main change came by the independent decision of farmers to use groundwater as a substitute or to supplement for direct surface water irrigation. The explosion in the installation of private tubewells within the Pakistani provinces in the Indus basin is shown in Fig. 7a. With a total of about 822000 , more than $85 \%$ of private tubewells are currently located in the Punjab province. Especially after 1990 the increase in private tubewells went extremely fast. In 2005 the total amount was almost 1 million. The amount of public tubewells was only 20000 (GOP, 2005). As a result, groundwater abstraction in Punjab from 1965 to 2002 has increased from $9 \mathrm{~km}^{3}$ to $45 \mathrm{~km}^{3}$ (Qureshi et al., 2009). The total groundwater withdrawal in the Pakistani part of the basin currently amounts to $52 \mathrm{~km}^{3}$ (Fig. 3). In the Indian states of the Indus basin the same observation can be made. Figure $7 \mathrm{~b}$ shows the changes in net irrigated area under surface water and groundwater from 1993-1994 to 2000-2001 in the main provinces of the Punjabs and Sindh. Over this period, for example, the net irrigated area under surface irrigation in Pakistani Punjab decreased from 4.2 to 3.7 million ha (decrease of $12 \%$ ) and the net irrigated area with groundwater increased from 8.8 to 10.3 million ha (increase of $18 \%$ ). The same observation is made in Sindh and Indian Punjab. In the latter the net irrigated area under surface irrigation 


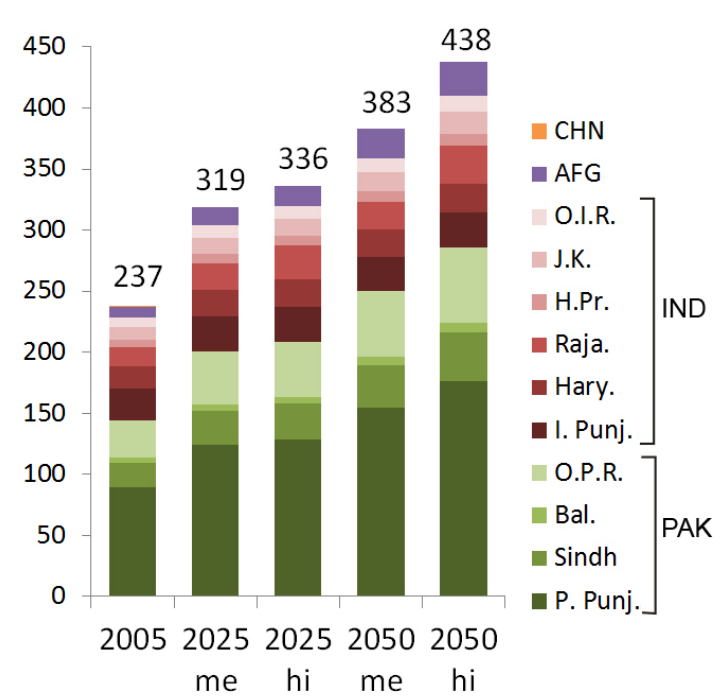

Fig. 6. Population projection data for the different regions within the borders of the Indus basin for 2025 and 2050. The regions and their codes are displayed in Fig. 4; me=medium population increase estimate; hi = high population increase estimate; data sources: UN (2011) for PAK, AFG and the Indian states of Himachal Pradesh, Jammu and Kashmir and other regions, Mahmood and Kundu (2008) for the Indian states Punjab, Haryana and Rajasthan.

decreased from 1.3 to 1.0 million ha (decrease of $25 \%$ ) and the net irrigated area with groundwater increased from 2.6 to 3.1 million ha (increase of $17 \%$ ). Also Shah et al. (2009) indicate that in Pakistan's Indus Basin Irrigation System, the area irrigated with tubewells increased during $1990-2006$ by $38 \%$ while that under flow irrigation declined by $11 \%$. Public irrigation is shrinking rapidly, whereas private irrigation is growing rapidly. The IBIS is a gravity run system with minimum management and operational requirements (Qureshi et al., 2009). Its operation is based upon a continuous water supply and is not related to actual crop water requirements. Despite significant increases in storage capacities, it is essentially a supply-based system. It can thus not accommodate changing water demands during the crop season. Groundwater exploitation has enabled many farmers to supplement their irrigation requirements and to cope with the uncertainties of surface supplies. The access to the natural buffer of groundwater resources has helped poor farmers not only to increase their production and incomes, but also enhance their opportunities to diversify their income base and to reduce their vulnerability against seasonality of agricultural production and external shocks such as droughts. This is a first reason for the drastic increase in groundwater use: the inability of the large irrigation systems to meet the variable and ondemand nature of the farmers' water requirements, as well as their poor maintenance and management.

However, current groundwater exploitation rates are unsustainable in many regions. There is a large imbalance between extraction and replenishment. Water tables are falling at alarming rates, both on the Pakistani (Qureshi et al., 2009; Tiwari et al., 2009) and Indian sides (Rodell et al., 2009; Sundarajan et al., 2008; Tiwari et al., 2009). For the Indus basin Tiwari et al. (2009) estimated a change (loss) of terrestrial water storage of about $10 \mathrm{~km}^{3} \mathrm{yr}^{-1}$ between April 2002 and June 2008. The Indian Ministry of Water Resources (Indian M.W.R., 2011) lists for the Indian states of Punjab and Haryana an annual overdraft of $9.89 \mathrm{~km}^{3}$ (stage of groundwater development $145 \%$ ) and $1 \mathrm{~km}^{3}$ (stage of groundwater development $109 \%$ ), respectively. Excessive lowering of the groundwater table has made pumping more expensive. As a result, many wells have gone out of production, yet the water table continues to decline and salinity increases.

A factor which also contributed to the increase in groundwater withdrawals is simply the increase in cropped and irrigated areas during the past decades as well as the increased cultivation of more water intensive crops like rice, cotton and sugarcane. The harvested area of these crops accounted for $20 \% 13 \%$ and $3 \%$, respectively, of all harvested area under irrigation in the year 2000 (Fig. 4). The principal regions where these crops are grown are the both Punjabs and to a lesser extent Haryana and Sindh. The irrigation of these 3 crops accounts for $28 \% 19 \%$ and $13 \%$, respectively, of the total blue water consumption in the basin (Fig. 4). These values show their water intensive nature as compared to the harvested areas. Figure 8 a shows the increase in both the area (million ha) and production (million $t$ ) of rice (basmati and other varieties) in Pakistani Punjab from 19871988 to 2004-2005. Note the increasing gap between area and production due to increased yields. Punjab accounts for more than $50 \%$ of the total rice production and more than $90 \%$ of the total basmati production in Pakistan. About 70$80 \%$ of rice produced in the province is basmati. However, large quantities of rice produced in Pakistan are for export (Fig. 8b). From 2001 to 2005, about 40-60\% of all rice produced in Pakistan was exported. Basmati exports increased from 0.6 to 0.9 million $t$ during that period.

\subsection{Flooding}

Flooding has always been an issue in the Indus basin (Tariq and van de Giesen, 2011). Monsoon rainfalls are the main source of floods in the basin. High flows are experienced in summer due to the increased rate of meltwater and monsoon rains. The nature of flooding varies according to geography. Fluvial floods in the Indus plain prove most devastating, as the terrain is flat, densely populated and economically developed. Hill torrents (flash floods) are the second most destructive type of flood.

The July-August 2010 floods in Pakistan were one of the greatest river disasters in recent history (Gaurav et al., 2011; Houze et al., 2011; Mustafa and Wrathall, 2011; Webster et al., 2011). More than 20 million people were affected, 

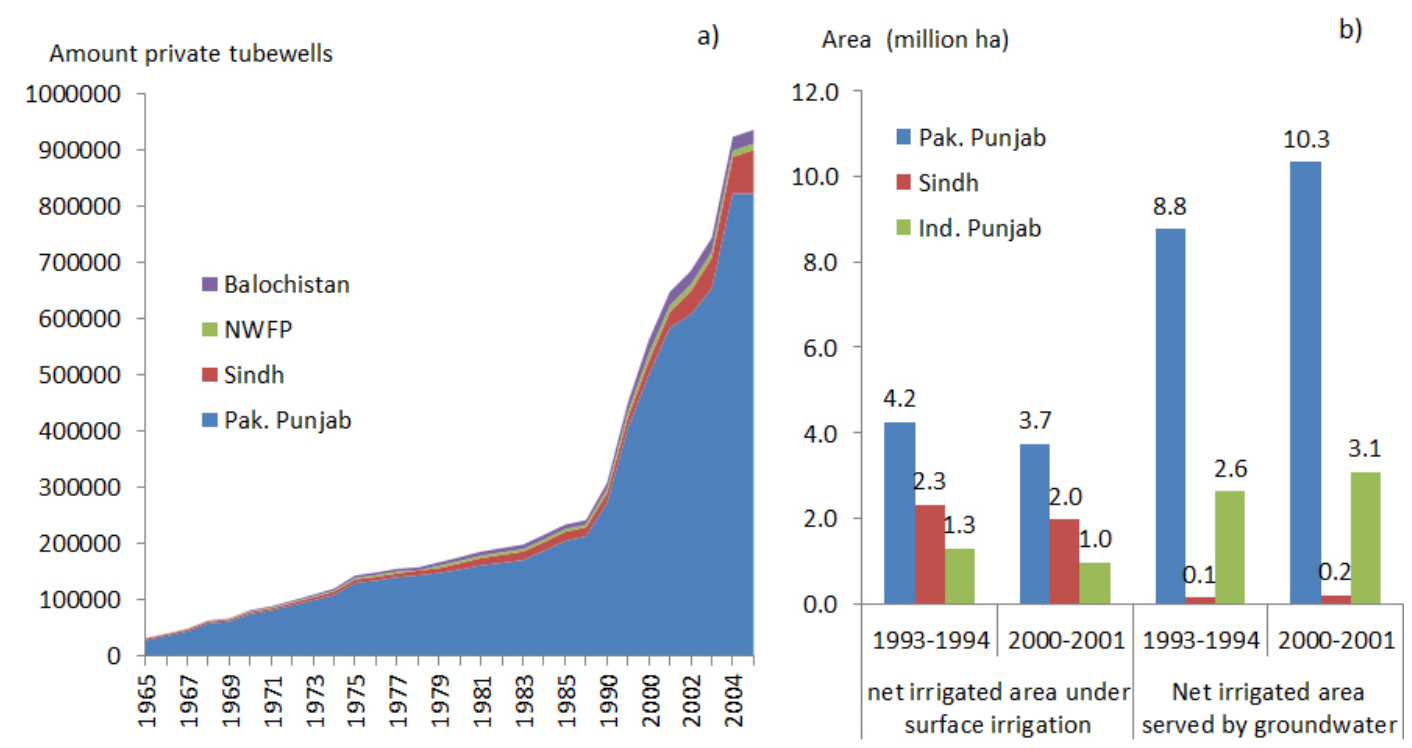

Fig. 7. (a) Increase in private tubewells in the main Pakistani provinces of the Indus Basin. Data source: GOP (2005); (b) net irrigated area under surface and groundwater irrigation for the periods 1993-1994 and 2000-2001 for the 3 provinces Sindh, Pakistani and Indian Punjab. Data Source: Shah et al. (2009) for Pak. Punjab and Sindh; Minor Irrigation Census 1993-1994 (Government of India, 2001; CWC, 2010) for Indian Punjab.

almost 2000 lost their lives and financial damages were in the range of 40 billion dollars (Webster et al., 2011). Although excessive rainfall has been cited as the major causative factor for this disaster (Houze et al., 2011; Tariq and van de Giesen, 2011), the human interventions in the river system over the years made this disaster a catastrophe (Gaurav et al., 2011). Also its geomorphic character with a high sediment load, typical for many Himalayan rivers, adds to the extent of the catastrophe and the unpredictability of the river. As a matter of fact, Gaurav et al. (2011) compare the 2010 Indus floods to the Kosi disaster in 2008 in India because of many similarities. The average annual sediment load - originating from the relatively young Karakoram and Himalaya mountains ranges - of 291 million t per year (Gaurav et al., 2011), ranks the Indus as one of the highest sediment load carrying rivers in the world.

Geomorphic analysis suggests that the Indus River has had a very dynamic regime in the past. However, the river has now been constrained by embankments on both sides, cutting it off from its natural floodplains. Barrages and dams were built. Flood control strategies on Himalayan rivers are primarily embankment based. Therefore the river has been accumulating sediment and aggrading rapidly during the last decades, making it a "superelevated river" in several reaches, which is considered to be prone to avulsion. Deforestation in the basin has led to increased erosion and sedimentation (Da Silva and Koma, 2011; Ali et al., 2005), as well as faster flood runoffs. The draining of natural wetlands has increased flooding. The wetlands that once surrounded the Indus River tamed floods, by regularly taking up parts of flood waters during monsoonal seasons and slowly releasing them again. Change in flow regimes due to low flows in eastern rivers after the Indus Water Treaty and enhanced flood protection measures have attracted economic activities and settlements in the floodplains, in a country with an increasing population and substantial poverty. Vulnerability on such locations has increased due to a false sense of safety. Due to increased settlements and constructions in the floodplains, water that enters the inundation zone has its drainage path back to the main river interrupted by levees, roads, railway lines and canal embankments. The result is that water does not drain back. The relationship between anthropogenic environmental degradation and catastrophic flooding is well documented (Mustafa and Wrathall, 2011). Conversely, we know there is an established link between healthy watersheds with flow capacity - wetlands, marshes, estuaries and mangroves - and flood mitigation. This disaster has stressed the urgent need to move from "river control" to "river management" strategies. The latter will be discussed in the following Sect. 4.1.4 "Land use planning and soil conservation; flood management".

\section{Recommendations in the framework of water resources management (WRM)}

Literature on solutions and alternative policy options for future sustainable WRM in the Indus Basin and India in general include (Gupta and Deshpande, 2004; Kumar et al., 2005; Sharma et al., 2010; Thakkar, 2008). Sustainable WRM practices include the management of water supply and the 

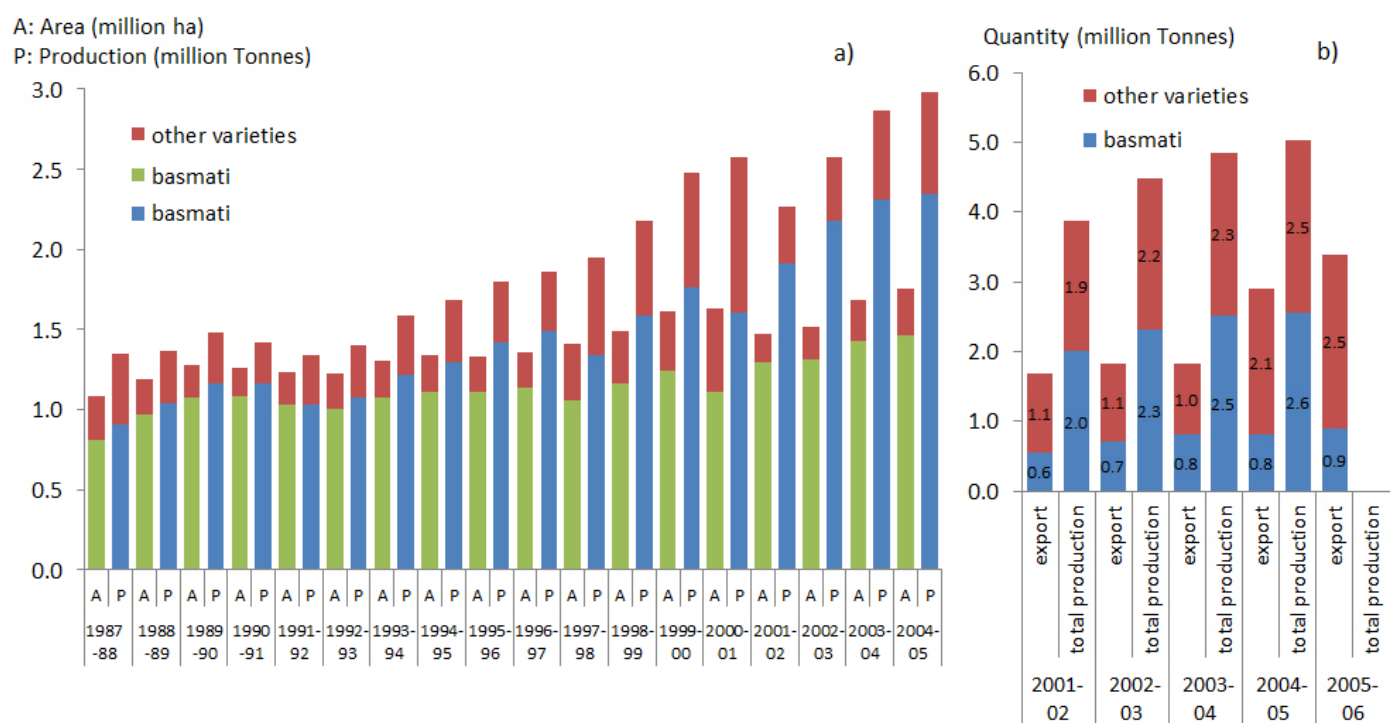

Fig. 8. (a) Area (million ha) and production (million t) of rice (basmati and other varieties) in Pakistani Punjab from 1987-1988 to 20042005. Data source: GOP (2005); (b) total production and export of rice (basmati and other varieties) for Pakistan from 2001-2002 to 2005-2006. Data source: GOP (2005).

managing of water demands. Applicable practices for the Indus basin are discussed in the following sections. Section 4.1 discusses water supply or availability management, Sect. 4.2 water demand management and Sect. 4.3 discusses the topic of international collaboration.

\subsection{Water supply-availability management}

\subsubsection{Reservoirs, rain water harvesting and artificial ground water recharge (AGWR)}

Due to the monsoonal characteristic of precipitation and the seasonal character of melt water flow in the basin as well as the seasonal changes in crop water demands, the storage of water and rain water is essential. In a system with little storage and considerable variability in both water demand and water availability, average water balance values can be deceptive. In the past large reservoirs have been built (e.g. the Tarbela Dam) and farmers gradually shifted from surface water usage to groundwater for irrigation to cope with these natural conditions. The use of the natural buffer of the groundwater reservoir has, however, led to an unsustainable fall of the groundwater table, draining aquifers faster than natural processes can replenish them (Qureshi et al., 2009; Rodell et al., 2009; Tiwari et al., 2009).

The 25 largest reservoirs in the basin represent a volume of $48.7 \mathrm{~km}^{3}$ (Fig. 3) - based upon the dataset of Lehner et al. (2008). Of this volume $22.2 \mathrm{~km}^{3}$ is located in India, especially in the reservoirs of the Pong Dam $\left(8.6 \mathrm{~km}^{3}\right)$ on the Beas River, Bhakra Dam $\left(9.6 \mathrm{~km}^{3}\right)$ on the Sutlej River and Thein Dam $\left(3.7 \mathrm{~km}^{3}\right)$ on the Ravi River. In Afghanistan the two included dams represent a volume of $0.6 \mathrm{~km}^{3}$. The remaining reservoir volume $\left(26 \mathrm{~km}^{3}\right)$ is located in Pakistan, especially in the reservoirs of the Tarbela Dam $\left(13.9 \mathrm{~km}^{3}\right)$ on the Indus River, Mangla Dam $\left(7.3 \mathrm{~km}^{3}\right)$ on the Jhelum River and Kalkri Lake $\left(2.5 \mathrm{~km}^{3}\right)$. However, a decline of reservoir storage due to sedimentation is observed in the Indus basin. The Indus River and its tributaries carry a very high sediment load which has seriously affected the storage capacity of these dams (Archer et al., 2010). The live storage capacity of the Indian dams is estimated to be $16.3 \mathrm{~km}^{3}$ (CWC, 2010). Sedimentation resulted in a reduction of $28 \%$ in the initial capacity of $13.9 \mathrm{~km}^{3}$ of Tarbela - commissioned in 1978 by 2000 and the useful life of the dam is now estimated to be $85 \mathrm{yr}$ (Archer et al., 2010). Similarly, the capacity of Mangla - completed in 1967 - was reduced by $20 \%$ by 2007, although a current project to raise Mangla will soon restore the capacity to an amount greater than when originally constructed (Archer et al., 2010). Of a total volume of $48.7 \mathrm{~km}^{3}$ about $39 \mathrm{~km}^{3}$ is currently available (when the Mangla volume is supposed to be $100 \%$ active). Replenishable groundwater resources amount to a volume of $27 \mathrm{~km}^{3}$ in India and $63 \mathrm{~km}^{3}$ in Pakistan (Fig. 3). When the latter are regarded as natural buffer or reservoir, the total reservoir volume is $129 \mathrm{~km}^{3}$. Nevertheless, unless new storage dams are built there will be a progressive reduction in active storage, which will seriously limit the capacity to transfer surplus summer flow to the winter (wheat) crop and downstream irrigation will return to run-of-river management. As described in the Sect. 3.2 "Water resources changes and climate change", on the long term there will be a substantial reduction of water availability during spring and summer. To compensate this, an increase in water storage is required. The loss of existing storage volume due to sedimentation needs to be reduced to 
a minimum by means of land management measures as described in the following Sect. 4.1.4 "Land use planning and soil conservation; flood management".

Reservoir management needs to be sophisticated to maximize yield from a given catchment and storage combination, the desire to minimize evaporative losses, and the demand for optimum water quality outcomes. There should be a multipurpose controlled management for hydropower generation, other uses and flooding control.

Apart from these multipurpose dams, decentralised rainwater harvesting can have a small impact in the Indus basin. Rainwater harvesting also prevents soil erosion, an essential matter in the basin. It can focus on (1) capturing water for domestic use (e.g. by rooftop rainfall collection); (2) replenishing green water (e.g. through stone bunds on the contour line); or (3) increasing blue water availability locally (e.g. through small check dams that increase recharge to the groundwater or store water in small reservoirs). Decentralised water harvesting is definitely an important factor for poor communities.

If suitable aquifers are accessible, AGWR has many benefits when compared to other storage options, e.g. low evaporation rates, natural treatment and storage capacity to buffer seasonal supply and demand variations. Basically the aquifers in the Indus basin have large reservoir capacities. The observed gradual depletion of the ground water table can be (partly) compensated by AGWR. It can compensate for the lack in reservoir storage which is highly vulnerable to sedimentation. This storage has to be conducted in the framework of IWRM. Also, Qureshi (2011) indicate that aquifer management is considered as the most effective way of establishing a balance between discharge and recharge components. In recent years, India has taken serious steps to use harvested rainwater to recharge its aquifers and recently allocated significant funds in the central government budget for further promotion of the practice.

Natural floodplains of the Indus and its tributaries should be maintained as much as possible. This topic is discussed in the Sect. 4.1.4 "Land use planning and soil conservation; flood management". With sustainable floodplain management, large water quantities of monsoon floods could be temporarily stored and groundwater reservoirs thereby replenished.

\subsubsection{Water quality conservation and investment in wastewater infrastructure}

The conservation of water quality and investment in wastewater infrastructure are a necessity in order to maintain the already quantitative scarce water availability. Especially the wastewater generated by municipalities, cities and industries should be purified before discharging them again in the receiving water bodies. In 2000, total wastewater produced in Pakistan was estimated at $12.33 \mathrm{~km}^{3}$ while treated wastewater was estimated at $0.135 \mathrm{~km}^{3}$; this is only $1 \%$. Total water withdrawn for domestic and industrial purposes in the Indus Basin is $8.8 \mathrm{~km}^{3}$ (Fig. 3). Water consumption values show that only about $11 \%$ of domestic water in the basin is consumed, the remaining $89 \%$ returns to the system. Industrial water is returned for $91 \%$ back to the system. In other words, $7.9 \mathrm{~km}^{3}$ of wastewater is returned to the system of which only a small fraction is purified. In order to maintain quality standards of the receiving water bodies, massive investments need to be made. Water quality conservation includes the implementation of water pollution prevention strategies (legislation, polluting taxes, ...) for the different polluters (Kumar et al., 2005). Society and individuals in the riparian countries should have a greater knowledge and ability to bring about the required changes and mentality.

Deteriorating groundwater quality is also a big issue in the Indus basin. The quality of groundwater in the basin varies from fresh to saline. Salinity remains a serious problem especially in the irrigated areas of the Sindh province, where much of the groundwater is naturally saline (of marine origin) and thus unsuitable for irrigation as a substitute for canal water. The joint management of surface and groundwater is a key requirement. Farmers need to be educated about suitable crops that can be grown under the conjunctive management of surface water and groundwater resources (Qureshi et al., 2009). In the Punjab provinces farmers largely rotate crops of wheat and paddy over the year. Since the Green revolution these intensive monocultures of wheat and paddy have displaced other crops. The immediate impact of intensive monoculture cultivation practices is seen on the soils, farmers have started using much larger doses of chemical fertilisers and pesticides in the last $50 \mathrm{yr}$. After Andhra Pradesh, per hectare application of fertilisers is the highest in Indian Punjab. These substances have contaminated water bodies. Additionally, groundwater in the Punjab is contaminated by urban runoff, seepage from contaminated industrial sites, and industrial discharges (Singh, 2001). A more green approach in farming is required and the policies that impose them. Quantification and timing of fertilisation has to be managed carefully in order to avoid water pollution.

\subsubsection{Use of alternate water resources}

Alternate water resources include the recycling of wastewater and desalination. Since both domestic and industrial water demands will increase substantially in the basin, so will the potential for recycled wastewater. As discussed in the previous section, about $90 \%$ of water withdrawn in the Indus basin for domestic and industrial purposes is returned to the water system $\left(7.9 \mathrm{~km}^{3}\right.$ of wastewater), predominately without purification in a treatment plant. The present water withdrawals for municipal and industrial uses in the whole of Pakistan are $5.4 \mathrm{~km}^{3}$. This demand is expected to increase to about $14 \mathrm{~km}^{3}$ by the year 2025 (Qureshi, 2011). Also in the Indian and Afghani parts of the basin domestic and industrial withdrawals will increase. The potential for recycled 
wastewater is therefore substantial. A general discussion on recycling of wastewater in India is given by Kumar (2009). A role model in sustainable urban water management and recycling of wastewater can be seen in Singapore (Vanham, 2011). The city state has invested and still is investing massively in a sustainable self-sufficient water supply system. Singapore aims at being self-sufficient in its water supply by effective measures like water recycling (NEWater) and desalinization, amongst others. Water purification is $100 \%$. By 2060 , the city plans to increase the current NEWater capacity so that NEWater can meet $50 \%$ of future water demand. Already today citizens are drinking recycled wastewater. The water cycle of the city is becoming more and more closed. Singapore has, of course, the financial and technical means to implement such a system. Nevertheless, the city shows sustainable solutions, which could also be implemented in the future in cities throughout the Indus Basin.

The use of domestic and industrial wastewater for irrigation also creates possibilities for irrigating crops. Not only will greater benefits be generated per unit of water diverted from a freshwater source, but some of the nutrients required to produce crops also will be recycled at a cost that is smaller than continuously developing new supplies. However, wastewater irrigation also creates health risks for farmers, their families, and consumers. An overview on the different aspects of wastewater for irrigation is given by Wichelns and Drechsel (2011). With increasing water withdrawals for domestic and industrial purposes, this issue offers a lot of opportunities as generally $90 \%$ of withdrawn water is returned to the system. When the bulk of this returned water is used for irrigation, a required reduction in irrigation requirements to meet other future demands will be not so substantial.

In the Sindh Province there are substantial deposits of brackish water in the underground. As the cost of desalinisation is falling (Kumar et al., 2005), the prospects of desalinating brackish water - and also seawater for the coastal communities - are becoming more attractive. Studies done in Pakistan and India have also shown that brackish water can be used for irrigating different crops under different soil types and environmental conditions (Qadir et al., 2001; Sharma and Rao, 1998).

\subsubsection{Land use planning and soil conservation; flood management}

These practices include a change of land use, reforestation and the reduced sealing of areas in order to prevent erosion and high surface flow coefficients. As discussed in the Sect. 3.5 "Flooding", erosion and the resulting high sedimentation loads in the river system of the Indus basin lead to the rise of the river beds between their embankments as well as the level of floodplains, diminishing their buffer capacity. Additionally the capacity of reservoirs is reduced substantially due to sedimentation. An important cause of increased sedimentation is past deforestation (Da Silva and
Koma, 2011). Current forests should be maintained and reforestation should be considered as an option to reduce erosion, especially in the mountainous regions of the basin to control flash floods. Erosion can also be reduced within agricultural zones by particular resource-conserving agricultural practices. For an overview on such practices refer to Bossio et al. (2010). These include agroforestry (the incorporation of trees into agricultural systems) or conservation agriculture (which combines non-inversion tillage (minimum or zero tillage in place of plowing) with mulching or cover cropping and crop rotation).

The 2010 floods in the Indus Basin stressed the urgent need to move from "river control" to "river management" strategies (Gaurav et al., 2011). Alternatives to embankments for flood management must be implemented with an emphasis on the "living with the flood" concept. Floodplain zoning and mapping projects need to be completed on priority basin (Tariq and van de Giesen, 2011; Gaurav et al., 2011). Basinscale flood risk maps should be based on historical data as well as modelling approaches. They could be linked to an online database and flood warning system.

Where possible wetlands should be restored and inundation zones should be implemented. In the past, wetlands have generally been considered as wastelands, and have been used for drainage of water, reclaimed for agriculture, or treated as dumping grounds for all kind of refuse (Briscoe and Qamar, 2007). Both wetlands and inundation zones would have a large impact in moderating high flow peaks, in addition to providing important ecosystem services such as groundwater recharge and biodiversity benefits (Mustafa and Wrathall, 2011). People living in such inundation zones could be relocated after fair and just compensation. Water managers and engineers of the Indus basin need to be sensitised to the need for adapting to the rhythm of the Indus basin rivers instead of the urge for engineering to control the river. Especially in the wake of climate change, due to which the monsoons will become more unpredictable, the idea of controlling the rivers $100 \%$ is an illusion.

\subsection{Water demand management}

\subsubsection{Managing conjunctive use of surface and groundwater}

The explosion in groundwater use has led to an unsustainable depletion of groundwater resources. Within Sect. 3.4 this phenomenon has been discussed in detail. It is identified as one of the major challenges for the Indus basin. Due to the enormous number of wells installed by small farmers, licensing is not the best option to resolve this, as observed in both Pakistan and India (Qureshi et al., 2009). The conjunctive use of surface and groundwater by farmers should be managed as described by Qureshi et al. (2009). The unmanaged conjunctive use of surface and groundwater at the head ends of the canals causes water tables to rise resulting 
in waterlogging whereas at the tail-ends salinity problems are increasing. Through the encouragement of planned conjunctive use this situation can be improved. Upstream farmers should make better use of the surface supplies - more reliable to them - in the canals. For this purpose, the canal department needs to regulate the canal flows to match the requirements.

\subsubsection{Rehabilitation and modernization of existing infrastructure}

Existing infrastructure for domestic, industrial and agricultural water supply should be rehabilitated and modernised. Leakage reduction in domestic water use should be addressed. A major task is adapting yesterday's irrigation systems to tomorrow's needs. Modernization, a mix of technological and managerial upgrading to improve responsiveness to stakeholder needs, will enable more productive and sustainable irrigation. The average irrigation efficiency in India is about $40 \%$ for surface and $60 \%$ for groundwater irrigation (Singh, 2007). Total crop consumption in the Indian part of the Indus basin is $35 \mathrm{~km}^{3}$ for $94 \mathrm{~km}^{3}$ withdrawn (Fig. 3). Irrigation efficiencies in the IBIS are also very low (Archer et al., 2010). Of the $175 \mathrm{~km}^{3}$ available surface water resources, about $125 \mathrm{~km}^{3}(72 \%)$ is withdrawn in the IBIS (Fig. 3). About $25 \%$ of this amount $\left(31 \mathrm{~km}^{3}\right)$ can be quantified as conveyance loss in the canal system. Due to water course conveyance losses and field application losses, $69 \mathrm{~km}^{3}$ according to Kreutzmann (2011) or $99 \mathrm{~km}^{3}$ according to the dataset (GWSP, 2008) are still available for irrigation agriculture as blue water consumption (Fig. 3). This low value is responsible for the continuous shortage of irrigation water in Pakistan as a whole and especially in tail-enders such as Sindh province. The present methods of surface irrigation are wasteful and larger doses of through flood irrigation with fresh water only add to the non-retrievable pool of poor quality saline groundwater. As such irrigation infrastructure should enable farmers to apply just the right amount of water in small and frequent quantities (e.g. by installation of drip or sprinkler irrigation). Irrigation efficiencies can also be increased by reducing irrigation canal leakage.

\subsubsection{Increasing water productivity (WP) for agriculture (irrigated and rainfed)}

Basically the crop system in the Indus basin is a rice-wheat system. During kharif (summer months, wet season, autumn harvest) rice is grown. In Indian Punjab sowing occurs from Mai to July and harvest from September to October (CWC, 2010). Other kharif crops include cotton, sugarcane and maize. During rabi (winter months, dry season, spring harvest, water availability is generally lower) wheat is grown. In Indian Punjab sowing occurs from October to November and harvest from April to Mai (CWC, 2010).
An overview on crop areas and harvested areas is shown in Fig. 4. Dominant agricultural production regions are the two Punjabs, Indian Haryana and Pakistani Sindh. The crop area and harvested area under irrigation for the five main crops - wheat, rice, sugarcane, maize and cotton - are also displayed in Fig. 4. Figure 8 displays the area and production of rice (basmati and other varieties) in Pakistani Punjab from 1987-1988 to 2004-2005. This province accounts for more than $50 \%$ of the total rice production and more than $90 \%$ of the total basmati production in Pakistan.

An overview on yields in selected states/regions in the Indus basin and national averages (India and Pakistan) for the period 1950-1951 to 2008-2009 for the four major crops rice, wheat, cotton and sugarcane is displayed in Fig. 9. It is shown that average yields generally rose during the past decades. The average yield of rice, e.g. in India, rose from about $1000 \mathrm{~kg}$ per ha in 1960 to more than $2000 \mathrm{~kg}$ per ha currently. Similarly the average yield of rice in Pakistan rose from about $1500 \mathrm{~kg}$ per ha in the eighties to about $2000 \mathrm{~kg}$ per ha at the beginning of this century. The average yield of wheat in India rose from about $850 \mathrm{~kg}$ per ha in 1960 to almost $3000 \mathrm{~kg}$ per ha currently. Similarly, the average yield of wheat in Pakistan rose from about $1700 \mathrm{~kg}$ per ha in the eighties to about $2500 \mathrm{~kg}$ per ha at the beginning of this century. There is also an important difference in yields of a certain crop between different regions in the Indus basin and production method. Yields are very high in certain areas and low in other regions of the basin. In the Indian Punjab, for example the yield of irrigated rice is more than $3500 \mathrm{~kg}$ per ha, whereas the yield of rainfed rice in Himachal Pradesh is only about $1500 \mathrm{~kg}$ per ha. The average rice yield in India is about $2000 \mathrm{~kg}$ per ha. Average rice yields of basmati rice in Pakistan are only about $1500 \mathrm{~kg}$ per ha. The same observations are valid for wheat. As a country average in Pakistan and India, the yield of wheat increased to about $2500 \mathrm{~kg}$ per ha in 2005. In the Indian Punjab irrigated wheat has an average yield of more than $4000 \mathrm{~kg}$ per ha, although rainfed wheat in the same province only has an average yield half of this value. The figure also shows that average yields of cotton are much less than the yields of wheat and rice, which are in the same range. Especially rainfed cotton has low yields (e.g. about $250 \mathrm{~kg}$ per ha in Haryana) whereas irrigated cotton yields are higher. Cotton yields are lower in India as compared to Pakistan. Sugar cane has very high yields, ranging from about $25000 \mathrm{~kg}$ per ha as rainfed sugarcane in Haryana up to $60000 \mathrm{~kg}$ per ha in the same state.

Figure 5 displays the average annual blue and green water consumption of crops in the Indus basin for the period 1996-2005, based upon data from Mekonnen and Hoekstra (2010b). The authors estimate blue water crop consumption at $117 \mathrm{~km}^{3}$ annually. Wheat blue water consumption is estimated as the highest fraction of total consumption, i.e. $41 \mathrm{~km}^{3}(35 \%)$. Additionally the green water consumption of wheat is estimated at $23 \mathrm{~km}^{3}$. The sum of green and blue water consumption is thus $64 \mathrm{~km}^{3}$. During 1996-2005 

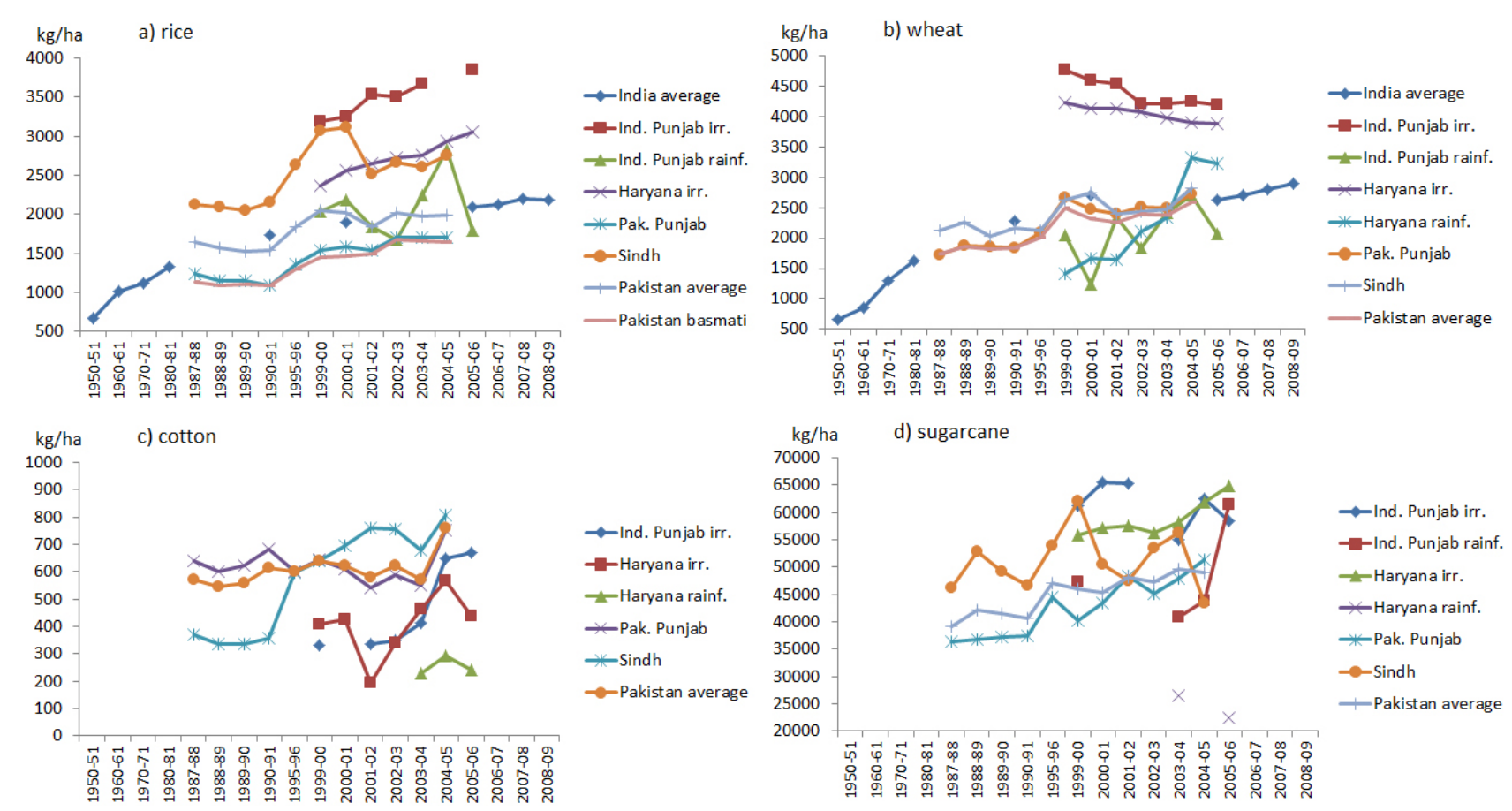

Fig. 9. Yield (in kg per ha) in selected states/regions in the Indus basin and national averages (India and Pakistan) for the period 1950-1951 to 2008-2009 of (a) rice; (b) wheat; (c) cotton and (d) sugarcane. Data sources: for Pakistan (GOP, 2005), for India (CWC, 2010).

the total annual production of wheat in the Pakistani part of the Indus Basin was about 18.5 million $\mathrm{t}(98 \%$ of total Pakistani production) whereas in the Indian part of the basin this amount was 18.7 million $t$ ( $27 \%$ of total Indian production). For the total basin production, this results in an average WP of $0.6 \mathrm{~kg} \mathrm{~km}^{-3}$ for wheat. For the Indo-Gangetic basin, Cai et al. (2010) state an average value for wheat of $0.94 \mathrm{~kg} \mathrm{~m}^{-3}$. For the IBIS, Bastiaanssen et al., (2003) state a productivity per unit consumed of $0.64 \mathrm{~kg} \mathrm{~m}^{-3}$. The same authors list for the IBIS a WP of $0.42 \mathrm{~kg} \mathrm{~m}^{-3}$ for rice, $0.22 \mathrm{~kg} \mathrm{~m}^{-3}$ for cotton and $4.79 \mathrm{~kg} \mathrm{~m}^{-3}$ for sugarcane. For the Indo-Gangetic basin, Cai et al. (2010) state an average value for rice of $0.74 \mathrm{~kg} \mathrm{~m}^{-3}$. In Indian Punjab this value is $1.18 \mathrm{~kg} \mathrm{~m}^{-3}$, whereas in the Pakistani part of the basin it is $0.69 \mathrm{~kg} \mathrm{~m}^{3}$. Cai et al. (2010) and Mahajan et al. (2009) give a value of 1.11.63 for rice in Indian Punjab. According to Mekonnen and Hoekstra (2010b), the blue water consumption of rice in the Indus basin is $29 \mathrm{~km}^{3}$ and the green water consumption is $18 \mathrm{~km}^{3}$. For a total annual production of 17.6 million $\mathrm{t}$ (of which 4.6 million $t$ in Pakistan, GOP, 2005 and 13 million $t$ in India - 9.2 million t in Punjab alone) the WP is $0.37 \mathrm{~kg} \mathrm{~m}^{-3}$, considerable lower than wheat. In Pakistan the fraction of blue water to total consumption is relatively higher than in India. Not included in these consumption values is the additional percolation water required for traditional rice production. Only for Pakistan, Chapagain and Hoekstra (2011) estimate this value at $1.7 \mathrm{~km}^{3}$ green water and $9.6 \mathrm{~km}^{3}$ irrigation water. According to Mekonnen and Hoekstra (2010b), the blue water consumption of cotton in the Indus basin is $20 \mathrm{~km}^{3}$ and the green water consumption is $14 \mathrm{~km}^{3}$. For a total annual production of 17.6 million $\mathrm{t}$ (of which 5.1 million $\mathrm{t}$ in Pakistan and 0.7 million $\mathrm{t}$ in India), the WP is $0.17 \mathrm{~kg} \mathrm{~m}^{-3}$. The latter is a very low value, and cotton is defined as a water intensive crop. Gaining more yield and value from less water can reduce future demands for water, limiting environmental degradation and easing competition for water. Specific irrigation techniques (drip irrigation, sprinkler irrigation) that can deliver water at the appropriate timing and quantification for the different growing stages of the plants, have large potential for increasing water productivity. The percentage of irrigated area under drip irrigation, e.g. in Indian Punjab and Haryana, was $0.5 \%$ in 2000 whereas the potential for both states is estimated at $5.5 \%$ of total irrigated area (Narayanamoorthy, 2009). In $20050.5 \%$ of the irrigated area of Punjab was under sprinkler irrigation, whereas in Haryana this value was $30 \%$. For rice the system of SRI (System of Rice intensification) has a lot of potential. Average yields are considerably increased with this technique, with a reduction in water requirements up to $70 \%$. An overview of this methodology is given by Sharif (2011).

Additional approaches to increase water productivity include: (1) providing appropriate quantum of fertiliser to the crop to realize yield potential; (2) cropping planning and diversification (which will be discussed in the next Sect. 4.2.4); (3) increasing the value per unit of water by integrating livestock and fisheries in irrigated systems; (4) in 
situ soil and water management and water harvesting techniques (bunds, terracing, contour cultivation, land levelling, etc.). An overview on resource-conserving agricultural practices that increase water productivity is given by Bossio et al. (2010).

Not included in the WP values water withdrawals are lost in the system due to poor irrigation efficiencies. This topic was addressed in the previous Sect. 4.2.2 "Rehabilitation and modernization of existing infrastructure".

\subsubsection{Crop planning and diversification; concept virtual water import-export}

Cropping planning and diversification includes the growing of crops in regions where or at times of the year when ET requirements are lower. An example of a policy acting on this, is the Punjab Preservation of Sub-Soil Water Act (2010) which prevents farmers from transplanting of paddy before 15 June to reduce ET (groundwater pumpage and energy) during the extremely hot summer months. Pakistani Punjab and other states may also emulate such regulations.

Certain crops produced in the Indus basin are partially exported out of the basin. Especially rice is exported from Pakistan and rice and wheat from Indian Punjab to other Indian states. Figure 8 shows the area and production of rice (basmati and other varieties) in Pakistani Punjab from 19871988 to 2004-2005 and was discussed in Sect. 3.4 "Shift from surface water to groundwater use". Punjab province represents $90 \%$ of overall Basmati rice production and more than $50 \%$ of the total rice production in Pakistan. About $70-80 \%$ of rice produced here is basmati. However, from 2001 to 2005, about 40-60\% of all rice produced in Pakistan was exported (Fig. 8b). Basmati exports increased from 0.6 to 0.9 million $t$ during that period. As discussed in the previous Sect. 4.2.3 "Increasing water productivity (WP) for agriculture (irrigated and rainfed)", rice is a water intensive crop with an average WP of $0.37 \mathrm{~kg} \mathrm{~m}^{-3}$. Additionally, large quantities of water (percolation and soil moisture) are required in traditional rice production, which are not consumed by the plant. Especially basmati from Pakistan has low yields as displayed in Fig. 9. Therefore, it is to be re-evaluated whether the production of such a water intensive crop for export is defendable in the current and future situation of the Indus basin. Reducing areas under rice crop may be a long term policy by encouraging rice cultivation in wetter areas or growing water-efficient but high value crops. Also, Qureshi (2011) questions whether Pakistan should continue to grow rice for export or instead use this water for other crops that represent a comparative advantage for the country.

According to Verma et al. (2009), the state of Punjab is amongst the largest net virtual water exporters (total amount $20.9 \mathrm{~km}^{3}$ per year) within India. Basically large amounts of crops produced are consumed elsewhere in the country, outside the Indus basin. Proponents of the virtual water trade argue that if certain policies - where farmers receive highly subsidized agricultural inputs (including water for irrigation) and are assured high prices for the wheat and rice they produce as in Punjab - were to be revised in favour of the wetter Indian states, water rich states would no longer have to import virtual water from water scarce states (Verma et al., 2009). Since wheat is a low-value crop, one may question whether water allocation to wheat production for export in states such as Punjab is worth the cost (Mekonnen and Hoekstra, 2010a). Especially for products that are exported out of the Indus basin, an evaluation of benefits (economically and livelihoods) to costs (depletion of water resources) should be made.

\subsubsection{Economic instruments (e.g. water pricing)}

According to Singh (2007), part of the reason for the low irrigation efficiencies is the highly subsidized price of irrigation water that encourages the excessive application of water to crops. An overview of potentials, problems and prospects for water pricing for irrigation is given by Reddy (2009), and particularly for the Indus basin by Shah et al. (2006, 2009). However, Qureshi et al. (2009) argue that direct management of an economy with such a large number of farmers through enforcing laws, installing licensing and permit systems and establishing tradable property rights did not prove to be effective in Pakistan. In Pakistan, the use of electricity for groundwater pumping started in 1970s. During this period, all capital installation costs were borne by the government and electricity tariffs were based on a metering system. In the 1980s, the population of tube wells surged and due to increasing electricity costs, the government withdrew subsidies on electricity tariffs in the Punjab and the Sindh provinces. As a result, large numbers of electric tube wells were replaced with diesel tube wells. The massive increase in private tubewells, as displayed in Fig. 7a, is thus due to diesel pumps and not electric pumps (which amount has remained rather stable at about 100000 since the 1980s). Diesel pumps however increased from about 200000 in 1987 to 900000 in 2005 (GOP, 2005). This clearly shows that changing energy prices only forces farmers to shift from one mode of energy to another but could not help resolve the real issue of groundwater overdraft. Therefore, changing electricity pricing policies, as the case in parts of India, would have a minor impact on controlling the groundwater overdraft. This clearly demonstrates the need to search for more innovative ways to solve the problem of groundwater over-exploitation while maintaining the current levels of agricultural production in view of the increasing population. In the wake of this paper these options are not further explored.

\subsubsection{Changing food demand patterns and limiting post-harvest losses}

Influencing diets towards more water-efficient food mixes, such as less meat can be a demand management practise. 
Diets can be influenced through advertising campaigns and appropriate pricing of foods to reflect the scarce resources used in food production (de Fraiture and Wichelns, 2010). The food requirements of diets based on meat from grainfed cattle may require twice the water required to support vegetarian diets. A diet without meat requires an estimated 20001 per day to produce, while a diet high in grain-fed beef requires 50001 of water (Renault and Wallender, 2000). Thus, the potential to reduce pressure on water resources by changes in food consumption patterns seems high. However, in both rural and urban India, the demand for non-grain food crops (vegetables, fruits, oil crops, ...) and animal products (milk, chicken, eggs, fish, ...) is increasing (Amarasinghe et al., 2008). Increasing income and urbanization will further increase the demand for non-grain food products in the Indian and Pakistani diet.

Post-harvest losses can be reduced by improving transportation and storage infrastructure and systems. Estimates of agricultural produce lost in the steps between production and consumption are between $40 \%$ and $50 \%$ (Lundqvist et al., 2008). A study commissioned by the FAO (Gustavsson et al., 2011) has quantified the amount of global food losses and food waste. Roughly one third of the food produced in the world for human consumption every year - approximately 1.3 billion to - gets lost or wasted globally. Fruits and vegetables, plus roots and tubers have the highest wastage rates of any food. Food losses - occurring at the production, harvest, post-harvest and processing phases - are most important in developing countries. Food waste is more a problem in industrialized countries, most often caused by both retailers and consumers throwing perfectly edible foodstuffs into the trash. Per capita food loss in South Asia is about $125 \mathrm{~kg}$ a year, whereas per capita food waste is only $6-11 \mathrm{~kg}$ per year.

\subsection{International collaboration}

For nearly $50 \mathrm{yr}$ a relatively stable Indus Water Treaty (IWT) moderated competition for the Indus water between Pakistan and India (Miner et al., 2009). Rising demand for water in each nation could unsettle this stable relationship. For the benefit of their people, Pakistan and India could coordinate bilateral development and resolve issues rather than defer them.

The Permanent Indus Commission (PIC) is responsible for resolving disputes between India and Pakistan over the implementation of the Indus Waters Treaty. Disputes are managed primarily through regular meetings of the engineers and officials that make up the two national sections of the commission (Zawahri, 2009b). Monitoring development projects in the Indus river system by PIC has eased fears of cheating between India and Pakistan (including the confirmation of accuracy of all exchanged data) and helped promote compliance with the 1960 Indus Waters Treaty (Zawahri, 2009a).

\section{Conclusions}

The Indus river basin - shared by Pakistan, India, China and Afghanistan - is one of the most depleted river basins in the world. The basin is confronted with a list of current and future challenges. Irrigated agriculture is by far the most important water demand stakeholder, but water demands for domestic and industrial purposes are increasing, due to population increase (from currently 237 million people to 319 million in 2025 and 383 million in 2050), increased urbanisation and industrialisation and the rise in living standards. Water availability will decrease on the long run due to climate change. A shift from surface water to groundwater use resulted in rapid depletion of groundwater resources in the past. There is a large gap between water withdrawals for irrigation and actual water consumed for crop production. Irrigation efficiencies are low. Much of the surface water that enters the system is wasted (also to groundwater recharge). Other challenges in the basin include water logging and salinity, loss of productive agricultural land, land degradation and the contamination of surface and groundwater resources.

This paper lists all challenges for the Indus basin, provides for a review on the different water balance components as quantified by different authors and own quantifications (presented in Fig. 3) and identifies all applicable sustainable WRM practices to meet these challenges. The latter include both water supply management and water demand management options. In this sense it differs from available literature regarding the Indus basin up to this date. Different papers have been written on the basin with recommendations to cope with current and future challenges (e.g. Archer et al., 2010; Qureshi et al., 2009; Qureshi, 2011; Sharma et al., 2010). However, none of them gives a comprehensive overview on all recommendable options for the entire basin (including all 4 countries). Because the challenges are so massive and because sustainable WRM requires the inclusion of all available options, it is essential for scientists and policy makers to have a holistic vision for the Indus basin. In the past the focus has always been on the increase in water availability, mostly implemented by technical measures. Even now traditionally trained engineers often tend to look only for solutions within water supply management options. However, water resources are not a finite resource. Sustainable water management also requires for the incorporation of water demand management options. This paper shows that the challenges of the Indus basin need to be taken upon by a list of measures within both options. This needs to be done within the concept of IWRM, regarding the Indus basin as a natural system, independent of political borders, where flooding needs to be tackled by means of "river management" measures, not merely "river control" strategies. The past vision to engineer the natural river system to a network of water providing canals has led to the physical cut-off of the river to its floodplains and the loss of natural buffer capacity due 
to the drainage of wetlands. Due to both deforestation and one of the worldwide highest sediment loads, reservoirs in the Indus basin tend to lose their capacity rather fast. Only by accepting the natural character of the basin again, flooding can be addressed. Current forests should be maintained and reforestation should be considered as an option to reduce erosion. Floodplain zoning and mapping projects need to be completed on priority basin. Where possible wetlands should be restored and inundation zones should be implemented.

Water supply management options that need to be addressed to deal with the challenges of the Indus basin are: (1) reservoir management (an increase in reservoir storage and the implementation of artificial groundwater storage (AGWR)); (2) water quality conservation and investment in wastewater infrastructure; (3) the use of alternative water resources like the recycling of wastewater and desalination (with a substantial potential due to the future increase in domestic and industrial water demands in the basin); (4) land use planning and soil conservation as well as flood management.

In addition to the presented water supply management options, water demand management options are a necessity. Options that are applicable to the Indus basin and would have an important impact to deal with the basin's challenges are: (1) the management of conjunctive use of surface and groundwater; (2) the rehabilitation and modernization of existing infrastructure; (3) the increase of water productivity for agriculture; (4) crop planning and diversification including the critical assessment of agricultural export, especially (basmati) rice; (5) economic instruments and (6) changing food demand patterns and limiting post-harvest losses.

Edited by: A. Gelfan

\section{References}

Akhtar, A. M., Ahmad, A. N., and Booij, M. J.: The impact of climate change on the water resources of Hindukush-KarakorumHimalaya region under different glacier coverage scenarios, J. Hydrol., 355, 148-163, 2008.

Ali, J., Benjaminsen, T. A., Hammad, A. A., and Dick, O. B.: The road to deforestation: An assessment of forest loss and its causes in Basho Valley, Northern Pakistan, Global Environ. Change, 15, 370-380, doi:10.1016/j.gloenvcha.2005.06.004, 2005.

Allen, R. G., Pereira, L. S., Raes, D., and Smith, M.: Crop evapotranspiration - Guidelines for computing crop water requirements, FAO Irrigation and drainage paper 56, FAO - Food and Agriculture Organization of the United Nations, Rome, 1998.

Amarasinghe, U. A., Shah, T., and Malik, R. P. S.: India's Water Futures: Drivers of Change, Scenarios and Issues, in: Strategic Analyses of the National River Linking Project (NRLP) of India Series 1 - India's Water Future: Scenarios and Issues, edited by: Amarasinghe, U. A., Shah, T., and Malik, R. P. S., International Water Management Institute, Colombo, Sri Lanka, 101$113,2008$.
Archer, D. R.: Contrasting hydrological regimes in the upper Indus Basin, J. Hydrol., 274, 198-210, 2003.

Archer, D. R., Forsythe, N., Fowler, H. J., and Shah, S. M.: Sustainability of water resources management in the Indus Basin under changing climatic and socio economic conditions, Hydrol. Earth Syst. Sci., 14, 1669-1680, doi:10.5194/hess-14-16692010, 2010.

Armstrong, R., Raup, B., Khalsa, S. J. S., Barry, R., Kargel, J., Helm, C., and Kieffer, H.: GLIMS glacier database. Boulder, Colorado USA: National Snow and Ice Data Center, Digital media, http://glims.colorado.edu/glacierdata (last access: 1 December 2010), 2005.

Babel, M. S. and Wahid, S. M.: Freshwater under threat: South Asia, Asian Institute of Technology (AIT), United Nations Environment Programme (UNEP), 2008.

Bastiaanssen, W., Ahmad, M.-U.-D., and Tahir, Z.: Upscaling Water Productivity in Irrigated Agriculture Using Remote-sensing and GIS Technologies, in: Water Productivity in Agriculture: Limits and Opportunities for Improvement, edited by: Kijne, W., Barker, R., and Molden, D., CAB International, 2003.

Biswas, A. K.: Indus Water Treaty: the Negotiating Process, Water Int., 17, 201-209, 1992.

Bookhagen, B. and Burbank, D. W.: Toward a complete Himalayan hydrological budget: Spatiotemporal distribution of snowmelt and rainfall and their impact on river discharge, J. Geophys. Res., 115, F03019, doi:10.1029/2009jf001426, 2010.

Bossio, D., Geheb, K., and Critchley, W.: Managing water by managing land: Addressing land degradation to improve water productivity and rural livelihoods, Agr. Water Manage., 97, 536542, doi:10.1016/j.agwat.2008.12.001, 2010.

Briscoe, J. and Qamar, U.: Pakistan's Water economy running dry, Oxford University Press, Karachi, Commissioned by World Bank, 2007.

Cai, X., Sharma, B. R., Matin, M. A., Sharma, D., and Gunasinghe, S.: An Assessment of Crop Water Productivity in the Indus and Ganges River Basins: Current Status and Scope for Improvement, IWMI Research Report 140, International Water Management Institute (IWMI), Colombo, 2010.

Cai, X. L. and Sharma, B.: Remote sensing and census based assessment and scope for improvement of rice and wheat water productivity in the Indo-Gangetic Basin, Sci. China Ser. E, 52, 3300-3308, doi:10.1007/s11431-009-0346-3, 2009.

Cai, X. L. and Sharma, B. R.: Integrating remote sensing, census and weather data for an assessment of rice yield, water consumption and water productivity in the IndoGangetic river basin, Agr. Water Manage., 97, 309-316, doi.org/10.1016/j.agwat.2009.09.021, 2010.

Chapagain, A. K. and Hoekstra, A. Y.: The blue, green and grey water footprint of rice from production and consumption perspectives, Ecol. Econom., 70, 749-758, 2011.

CIESIN: Gridded Population of the World Version 3 (GPWv3), Palisades, NY, Socioeconomic Data and Applications Center (SEDAC), Columbia University, 2005.

CWC: Water and related statistics, Central Water Commission of India, 253 pp., 2010.

Da Silva, F. and Koma, A.: The 2010 Pakistan Flood Disaster: Caused by Man or Mother Nature?, The GLG 216 Journal, 5860, 2011. 
de Bie, K.: An updated Kppen-Geiger Climate Classification of the World using Very High Resolution Interpolated Climate Surfaces of monthly $P$ and $T$ data from 1950 to 2000 , ITC News, 16-17, 2007.

de Fraiture, C. and Wichelns, D.: Satisfying future water demands for agriculture, Agr. Water Manage., 97, 502-511, 2010.

Eastham, J. M., Kirby, M., Mainuddin, M., and Thomas, M.: Wateruse accounts in CPWF basins: Simple water-use accounting of the Indus basin, The CGIAR Challenge Program on Water and Food, CPWF Working Paper BFP07, Colombo, Sri Lanka, 27 pp., 2010.

Gaurav, K., Sinha, R., and Panda, P. K.: The Indus flood of 2010 in Pakistan: a perspective analysis using remote sensing data, Nat. Hazards, 59, 1815-1826, doi:10.1007/s11069-011-9869-6, 2011. GOP: Agricultural statistics of Pakistan, 2004-2005, Ministry of Food, Agriculture and Livestock, Government of Pakistan, 2005.

Government of India: Report on census of minor irrigation schemes 1993-1994, Ministry of Water Resources, New Delhi, India, 2001.

Gupta, S. K. and Deshpande, R. D.: Water for India in 2050: firstorder assessment of available options, Current Sci., 86, 12161224, 2004.

Gustavsson, J., Cederberg, C., Sonesson, U., van Otterdijk, R., and Meybeck, A.: Global Food Losses and Food Waste - Extent, Causes and Prevention, Swedish Institute for Food and Biotechnology (SIK), Gothenburg, Rome, 2011.

GWSP: Global Water System Project Digital Water Atlas data, http: //atlas.gwsp.org/ (last access: March 2012), 2008.

Harrington, L., Cook, S. E., Lemoalle, J., Kirby, M., Taylor, C., and Woolley, J.: Cross-basin comparisons of water use, water scarcity and their impact on livelihoods: present and future, Water Int., 34, 144-154, doi:10.1080/02508060802661584, 2009.

Hewitt, K.: The Karakoram Anomaly? Glacier Expansion and the "Elevation Effec", Karakoram Himalaya, Mount. Res. Dev., 25, 332-340, 2005.

Hijmans, R. J., Cameron, S. E., Parra, J. L., Jones, P. G., and Jarvis, A.: Very high resolution interpolated climate surfaces for global land areas, Int. J. Climatol., 25, 1965-1978, 2005.

Hoekstra, A. Y., and Mekonnen, M. M.: Global water scarcity: The monthly blue water footprint compared to blue water availability for the world's major river basins, UNESCO-IHE Institute for Water Education, The Netherlands Value of Water Research Report Series No. 53, Delft, 2011.

Houze, R. A., Rasmussen, K. L., Medina, S., Brodzik, S. R., and Romatschke, U.: Anomalous Atmospheric Events Leading to the Summer 2010 Floods in Pakistan, B. Am. Meteorol. Soc., 92, 291-298, 10.1175/2010bams3173.1, 2011.

Immerzeel, W. W., Droogers, P., de Jong, S. M., and Bierkens, M. F. P.: Large-scale monitoring of snow cover and runoff simulation in Himalayan river basins using remote sensing, Remote Sens. Environ., 113, 40-49, doi:10.1016/j.rse.2008.08.010, 2009.

Immerzeel, W. W., van Beek, L. P. H., and Bierkens, M. F. P.: Climate Change Will Affect the Asian Water Towers, Science, 328, 1382-1385, doi:10.1126/science.1183188, 2010.

Indian M.W.R.: Ground Water Resources Of The Country - state wise: http://wrmin.nic.in/writereaddata/linkimages/ Annexure-I3792665287.pdf, last access: 6 December 2001, Indian Ministry of Water Resources, 2011.
IUCN: Beyond Indus Water Treaty: Ground Water and Environmental Management - Policy Issues and Options, IUCN Pakistan, Karachi, 2010.

Jain, S., Goswami, A., and Saraf, A.: Assessment of snowmelt runoff using remote sensing and effect of climate change on runoff, Water Resour. Manage., 24, 1763-1777, 2009.

Karim, A. and Veizer, J.: Water balance of the Indus River Basin and moisture source in the Karakoram and western Himalayas: Implications from hydrogen and oxygen isotopes in river water, J. Geophys. Res., 107, 4362, doi:10.1029/2000jd000253, 2002.

Karki, M. B., Shrestha, A. B., and Winiger, M.: Enhancing Knowledge Management and Adaptation Capacity for Integrated Management of Water Resources in the Indus River Basin, Mount. Res. Dev., 31, 242-251, doi:10.1659/MRD-JOURNAL-D-1100017.1, 2011.

Kaser, G., Grosshauser, M., and Marzeion, B.: Contribution potential of glaciers to water availability in different climate regimes, P. Natl. Acad. Sci., 107, 20223-20227, 2010.

Kerr, R. A.: Northern India's Groundwater Is Going, Going, Going ..., Science, 325, 798, doi:10.1126/science.325_798, 2009.

Khan, N. M. and Tingsanchali, T.: Optimization and simulation of reservoir operation with sediment evacuation: a case study of the Tarbela Dam, Pakistan, Hydrol. Process., 23, 730-747, 2009.

Köppen, W.: Das geographisca System der Klimate, in: Handbuch der Klimatologie, edited by: Köppen, W. and Geiger, G., 1. C, Gebr. Borntraeger, 1-44, 1936.

Kreutzmann, H.: Scarcity within opulence: Water management in the Karakoram Mountains revisited, J. Mount. Sci., 8, 525-534, doi:10.1007/s11629-011-2213-5, 2011.

Kumar, M.: Reclamation and reuse of treated municipal wastewater: an option to mitigate water stress, Current Sci., 96, 886-889, 2009.

Kumar, R., Singh, R. D., and Sharma, K. D.: Water resources of India, Current Sci., 89, 794-811, 2005.

Lashkaripour, G. and Hussaini, S.: Water resource management in Kabul river basin, eastern Afghanistan, Environmentalist, 28, 253-260, doi:10.1007/s10669-007-9136-2, 2008.

Lehner, B., R-Liermann, C., Revenga, C., Vörösmarty, C., Fekete, B., Crouzet, P., and Döll, P. E. A.: High resolution mapping of the world's reservoirs and dams for sustainable river flow management, Frontiers in Ecology and the Environment, Source: GWSP Digital Water Atlas 2008, Map 2081: GRanD Database, Dataset, V2001.2000, 2008.

Leichenko, R. M. and Wescoat, J. L.: Environmental impacts of climate change and water development in the Indus delta region, Int. J. Water Resour. D., 9, 247-261, 1993.

Lundqvist, J., de Fraiture, C., and Molden, D.: Saving Water: From Field to Fork - Curbing Losses and Wastage in the Food Chain, SIWI Policy Brief, SIWI, Stockholm, Sweden, 2008.

Mahajan, G., Bharaj, T. S., and Timsina, J.: Yield and water productivity of rice as affected by time of transplanting in Punjab, India, Agr. Water Manage., 96, 525-532, 2009.

Mahmood, A. and Kundu, A.: Demographic Projections for India 2006-2051: Regional Variations, in: Strategic Analyses of the National River Linking Project (NRLP) of India Series 1 - India's Water Future: Scenarios and Issues, edited by: Amarasinghe, U. A., Shah, T., and Malik, R. P. S., IWMI, Colombo, Sri Lanka, 101-113, 2008. 
Mekonnen, M. M. and Hoekstra, A. Y.: A global and highresolution assessment of the green, blue and grey water footprint of wheat, Hydrol. Earth Syst. Sci., 14, 1259-1276, doi:10.5194/hess-14-1259-2010, 2010a.

Mekonnen, M. M. and Hoekstra, A. Y.: The green, blue and grey water footprint of crops and derived crop products, UNESCOIHE Institute for Water Education, The Netherlands Value of Water Research Report Series No. 47, Delft, 2010b.

Miner, M., Patankar, G., Gamkhar, S., and Eaton, D. J.: Water sharing between India and Pakistan: a critical evaluation of the Indus Water Treaty, Water Int., 34, 204-216, 2009.

Mitchell, T. D. and Jones, P. D.: An improved method of constructing a database of monthly climate observations and associated high-resolution grids, Int. J. Climatol., 25, 693-712, 2005.

Molle, F., Wester, P., and Hirsch, P.: River basin closure: Processes, implications and responses, Agr. Water Manage., 97, 569-577, doi:10.1016/j.agwat.2009.01.004, 2010.

Mukhopadhyay, B.: Detection of dual effects of degradation of perennial snow and ice covers on the hydrologic regime of a Himalayan river basin by stream water availability modeling, J. Hydrol., 412-413, 14-33, doi:10.1016/j.jhydrol.2011.06.005, 2012.

Mustafa, D. and Wrathall, D.: The Indus basin floods of 2010: The cost of agricultural development?, in: On the Water Front: Selections from the 2010 World Water Week in Stockholm, edited by: Lundqvist, J., SIWI, Stockholm, 127-136, 2011.

Narayanamoorthy, A.: Drip and Sprinkler Irrigation in India: Benefits, Potential and Future Directions, in: Strategic Analyses of the National River Linking Project (NRLP) of India, Series 1, India's Water Future: Scenarios and Issues, edited by: Upali, A. and Amarasinghe, T. S. A. R. P. S. M., International Water Management Institute, Colombo, Sri Lanka, 253-266, 2009.

Portmann, F. T., Siebert, S., and Döll, P.: MIRCA2000 - Global Monthly Irrigated and Rainfed Crop Areas around the year 2000: A new high-resolution data set for agricultural and hydrological modeling, Global Biogeochem. Cy., 24, GB1011, doi:10.1029/2008GB003435, 2010.

Qadir, M., Ghafoor, A., and Murtaze, G.: Use of salinesodic waters through phytoremediation of calcarous saline sodic soils, Agr. Water Manage., 50, 197-210, doi:10.1016/S03783774(01)00101-9, 2001

Qureshi, A., McCornick, P., Sarwar, A., and Sharma, B.: Challenges and Prospects of Sustainable Groundwater Management in the Indus Basin, Pakistan, Water Resour. Manage., 24, 15511569, 10.1007/s11269-009-9513-3, 2009.

Qureshi, A. S.: Water Management in the Indus Basin in Pakistan: Challenges and Opportunities, Mount. Res. Dev., 31, 252-260, doi:10.1659/mrd-journal-d-11-00019.1, 2011.

Qureshi, S., McCornick, P. G., Qadir, M., and Aslam, Z.: Managing salinity and waterlogging in the Indus Basin of Pakistan, Agr. Water Manage., 95, 1-10, doi:10.1016/j.agwat.2007.09.014, 2008.

Raup, B. H., Kieffer, H. H., Hare, T. M., and Kargel, J. S.: Generation of Data Acquisition Requests for the ASTER Satellite Instrument for Monitoring a Globally Distributed Target: Glaciers, IEEE T. Geosci. Remote, 38, 1105-1112, 2000.

Reddy, V. R.: Water Pricing as a Demand Management Option: Potentials, Problems and Prospects, in: Strategic Analyses of the National River Linking Project (NRLP) of India Series 3 Promoting Irrigation Demand Managment in India: Potentials,
Problems and Prospects, edited by: Saleth, R. M., International Water Management Institute, Colombo, Sri Lanka, 101-113, 2009.

Renault, D. and Wallender, W. W.: Nutritional water productivity and diets, Agr. Water Manage., 45, 275-296, 2000.

Rodell, M., Velicogna, I., and Famiglietti, J. S.: Satellite-based estimates of groundwater depletion in India, Nature, 460, 999-1002, 2009.

Saleth, R. M. and Amarasinghe, U. A.: Promoting Irrigation Demand Management in India: Policy Options and Institutional Requirements, in: Strategic Analyses of the National River Linking Project (NRLP) of India, Series 3, Promoting irrigation demand managment in India: Potentials, problems and prospects, edited by: Saleth, R. M., International Water Management Institute, Colombo, Sri Lanka, 1-24, 2009.

Scherler, D., Bookhagen, B., and Strecker, M. R.: Spatially variable response of Himalayan glaciers to climate change affected by debris cover, Nat. Geosci., 4, 156-159, doi:10.1038/ngeo1068, 2011.

Scott, C. A. and Sharma, B.: Energy supply and the expansion of groundwater irrigation in the Indus-Ganges Basin, Intl. J. River Basin Manage., 7, 1-6, 2009.

Setchell, C. A. and Luther, C. N.: Kabul, Afghanisthan: a case study in responding to urban displacement, Humanitarian Exchange Magazine, 45, 2009.

Shah, T., Singh, O. P., and Mukherji, A.: Some aspects of South Asia's groundwater irrigation economy: analyses from a survey in India, Pakistan, Nepal Terai and Bangladesh, Hydrogeol. J., 14, 286-309, 2006.

Shah, T., Hassan, M. U., Khattak, M. Z., Banerjee, P. S., Singh, O. P., and Rehman, S. U.: Is Irrigation Water Free? A Reality Check in the Indo-Gangetic Basin, World Dev., 37, 422-434, 2009.

Sharif, A.: Technical adaptations for mechanized SRI production to achieve water saving and increased profitability in Punjab, Pakistan, Paddy Water Environ., 9, 111-119, doi:10.1007/s10333010-0223-5, 2011.

Sharma, B., Amarasinghe, U., Xueliang, C., de Condappa, D., Shah, T., Mukherji, A., Bharati, L., Ambili, G., Qureshi, A., Pant, D., Xenarios, S., Singh, R., and Smakhtin, V.: The Indus and the Ganges: river basins under extreme pressure, Water Int., 35, 493-521, 2010.

Sharma, B. R., Amarasinghe, U. A., and Sikka, A.: Indo-Gangetic River Basins: Summary Situation Analysis, International Water Management Institute (IWMI), New Delhi, 2008.

Sharma, D. P. and Rao, K. V. G. K.: Strategy for long-term use of saline drainage water in semi-arid regions, Soil Till. Res., 47 287-295, doi:10.1016/S0167-1987(98)00135-4, 1998.

Siebert, S., Dll, P., Hoogeveen, J., Faures, J.-M., Frenken, K., and Feick, S.: Development and validation of the global map of irrigation areas, Hydrol. Earth Syst. Sci., 9, 535-547, doi:10.5194/hess-9-535-2005, 2005.

Singh, K.: Rational Pricing of Water as an Instrument of Improving Water Use Efficiency in the Agricultural Sector: A Case Study in Gujarat, India, Water Resour. Dev., 23, 679-690, 2007.

Singh, P. and Bengtsson, L.: Hydrological sensitivity of a large Himalayan basin to climate change, Hydrol. Process., 18, 23632385, doi:10.1002/hyp.1468, 2004. 
Singh, R. B.: Impact of land-use change on groundwater in the Punjab-Haryana plains, India, IAHS Publ. no. 269, Proceedings of a symposium held during the Sixth IAHS Scientific Assembly at Maastricht, The Netherlands, 2001.

Sundarajan, K., Patel, A., Raychoudhury, T., and Purohit, C.: Groundwater Exploitation in India, Environmental Impacts and Limits to Further Exploitation for Irrigation, in: Strategic Analyses of the National River Linking Project (NRLP) of India Series 1 - India's Water Future: Scenarios and Issues, edited by: Amarasinghe, U. A., Shah, T., and Malik, R. P. S., IWMI, Colombo, Sri Lanka, 197-216, 2008.

Tahir, A. A., Chevallier, P., Arnaud, Y., and Ahmad, B.: Snow cover dynamics and hydrological regime of the Hunza River basin, Karakoram Range, Northern Pakistan, Hydrol. Earth Syst. Sci., 15, 2275-2290, doi:10.5194/hess-15-2275-2011, 2011.

Tariq, M. A. U. R. and van de Giesen, N.: Floods and flood management in Pakistan, J. Phys. Chem. Earth, doi:10.1016/j.pce.2011.08.014, in press, 2011.

Thakkar, H.: Future water solutions for India, Development, 51, 68-71, 2008.

Tiwari, V. M., Wahr, J., and Swenson, S.: Dwindling groundwater resources in northern India, from satellite gravity observations, Geophys. Res. Lett., 36, L18401, doi:10.1029/2009GL039401, 2009.

UN: Population Division of the Department of Economic and Social Affairs, World Population Prospects: The 2010 Revision: http://esa.un.org/unpd/wpp/unpp/panel_population.htm, last access: 5 December 2011.

UNEP: World Atlas of Desertification, Edward Arnold, London, UK, 1992.

UNEP: FreshWater under threat: South Asia, 44 pp., 2009.

Van Steenbergen, F. and Gohar, S.: Ground water development and Management, World Bank, Background paper 12, 2005.

Vanham, D.: How much water do we really use? A case study of the city state of Singapore, Water Sci.Technol., 11, 219-228, doi:110.2166/ws.2011.043, 2011.
Vanham, D., Fleischhacker, E., and Rauch, W.: Technical Note: Seasonality in alpine water resources management a regional assessment, Hydrol. Earth Syst. Sci., 12, 91-100, doi:10.5194/hess-12-91-2008, 2008.

Vanham, D., Millinger, S., Pliessnig, H., and Rauch, W.: Rasterised Water Demands: Methodology for Their Assessment and Possible Applications, Water Resour. Manage., 25, 3301-3320, doi:10.1007/s11269-011-9857-3, 2011a.

Vanham, D., Weingartner, R., and Rauch, W.: The Cauvery river basin in Southern India: major challenges and possible solutions in the 21st century, Water Sci. Technol., 64, 122-131, doi:10.2166/wst.2011.554, 2011 b.

Varis, O., Kummu, M., and Salmivaara, A.: Ten major rivers in monsoon Asia-Pacific: An assessment of vulnerability, Appl. Geogr., 32, 441-454, doi:10.1016/j.apgeog.2011.05.003, 2012.

Verma, S., Kampman, D. A., van der Zaag, P., and Hoekstra, A. Y.: Going against the flow: A critical analysis of inter-state virtual water trade in the context of India's National River Linking Program, Phys. Chem. Earth, 34, 261-269, 2009.

Webster, P. J., Toma, V. E., and Kim, H.-M.: Were the 2010 Pakistan floods predictable?, Geophys. Res. Lett., 38, L04806, doi:10.1029/2010GL046346, 2011.

Wichelns, D. and Drechsel, P.: Meeting the challenge of wastewater irrigation: economics, finance, business opportunities and methodological constraints, Water Int., 36, 415-419, doi:10.1080/02508060.2011.593732, 2011.

Winiger, M., Gumpert, M., and Yamout, H.: Karakorum - Hindukush - western Himalaya: assessing high-altitude water resources, Hydrol. Process., 19, 2329-2338, 2005.

Zawahri, N. A.: India, Pakistan, and Cooperation along the Indus River System, Water Policy, 11, 1-20, 2009a.

Zawahri, N. A.: Third Party Mediation of International River Disputes: Lessons from the Indus River, Int. Negot., 14, 281-310, 2009b. 